\title{
FIELD TECTONOPHYSICS IN SOLUTIONS OF GEODYNAMIC EVOLUTION PROBLEMS OF THE UKRAINE TERRITORY
}

\author{
O. B. Gintov, A. V. Murovskaya, S. V. Mychak \\ S.I. Subbotin Institute of Geophysics, NAS of Ukraine, Kiev, Ukraine
}

\begin{abstract}
The integrated approach combining kinematic and structural-paragenetic field tectonophysics techniques allows us to construct a continuous time scan of the stress-strain state (SSS) and deformation modes (DM) from sediment lithification to the final orogenic process for the studied areas. Definitions of the continuous sequence of SSS and DM provide for control of the known geodynamic reconstructions and adjustment of geodynamic models. An example is the tectonophysical study of the Alpine structural stage of the Western Mountainous Crimea (WMC) and the Pre-Cambrian complexes of the Ukrainian Shield (USh).

Data from WMC allow us to make adjustments to the geodynamic model of the Mountainous Crimea. In particular, trajectories of the principal normal stresses (Fig. 4 and 5), both for shifts and shear faults with reverse components/ normal faults, suggest the reverse nature of movements of the Eastern and Western Black Sea microplates with their overall pushing onto the Crimean peninsula in the south-east, south and south-west (Fig. 7). In the Precambrian USh complexes (Fig. 8), 13 stages of regional deformation are revealed between $\geq 2.7$ and 1.6 billion years ago. Until the turn of 2.05-2.10 billion years, the region was subject to transtension and transpression, as the Western (gneiss-granulite) and Eastern (granite-greenstone) Archean microplates of USh moved to separate from each other in the Neo-Archean and then diverged and converged in the Paleoproterozoic (movements at a sharp angle). It is assumed that in the Archean the Western and Eastern microplates were separated by the oceanic or sub-oceanic lithosphere (Fig. 12, 13). During the period of 2.3-2.4 billion years, the plates fully converged creating a zone of collision. It may be suggested that a possible mechanism for the oceanic window close-up was underthrusting of the upper suboceanic lithosphere layers beneath the crust-mantle plates on gently sloping break-up surfaces (non-subduction option), and one of them is Moho.

Spreading of the Western and Eastern microplates of USh began at the turn of 2.05-2.10 billion years, as evidenced by the available tectonophysical data on fields of latitudinal extension of the crust. During spreading 2.1-2.05 billion years ago, emanations and solutions were able to ascend into the upper crust and thus stimulate palingenesis (Novoukrainsky and Kirovogradsky granites), and during repeated spreading 1.75 billion years ago, magma of the basic and acid composition (Pluto gabbro-anorthosite and rapakivi) intruded into the upper crust. The spreading zone coincided with the former collisional suture and became the site wherein the inter-regional Kherson-Smolensk suture was formed; it stretches submeridionally across the East European platform.
\end{abstract}

Key words: geodynamics, field tectonophysics, microplate, transpression, transtension, stresses, strains, slickensides.

Recommended by Yu.L. Rebetsky

Citation: Gintov O.B., Murovskaya A.V., Mychak S.V. 2013. Field tectonophysics in solutions of geodynamic evolution problems of the Ukraine territory. Geodynamics \& Tectonophysics 4 (3), 281-299. doi:10.5800/GT2013-4-3-0101.

\section{ПОЛЕВАЯ ТЕКТОНОФИЗИКА В РЕШЕНИИ ПРОБЛЕМ ГЕОДИНАМИЧЕСКОГО РАЗВИТИЯ ТЕРРИТОРИИ УКРАИНЫ}

\author{
О. Б. Гинтов, А. В. Муровская, С. В. Мычак
}

Институт геофизики им. С.И. Субботина НАН Украины, Киев, Украина 
Аннотация: Комплексный подход, объединяющий кинематический и структурно-парагенетический методы полевой тектонофизики, позволяет строить непрерывную временную развертку напряженно-деформированных состояний (НДС) и деформационных режимов (ДР) изучаемых районов от литификации осадков до завершающего орогенического процесса. Определение непрерывной последовательности НДС и ДР позволяет контролировать уже известные геодинамические построения и корректировать геодинамические модели. Примером может служить тектонофизическое изучение альпийского структурного этажа Западного Горного Крыма (ЗГК) и докембрийских комплексов Украинского щита (УЩ).

Данные, полученные в ЗГК, позволяют внести коррективы в модель геодинамического развития Горного Крыма. В частности, траектории главных нормальных напряжений (рис. 4 и 5) как в сдвиговом, так и во взбросовом или сбросовом режимах, указывают на реверсный характер движений Восточно- и Западно-Черноморской микроплит при общем нажиме их на Крымский полуостров с юго-востока, юга и юго-запада (рис. 7). В докембрийских комплексах центральной части УЩ (рис. 8) установлены 13 этапов деформации региона между $\geq 2.7$ и 1.6 млрд лет назад. До рубежа 2.05-2.10 млрд лет назад регион развивался в режиме транстенсии и транспрессии, при котором Западная (гнейсово-гранулитовая) и Восточная (гранит-зеленокаменная) архейские микроплиты УЩ в неоархее расходились, а в палеопротерозое сближались и расходились под острым углом. Предполагается, что Западную и Восточную микроплиты в архее разделяла океаническая или субокеаническая литосфера (рис. 12, 13). В период 2.3-2.4 млрд лет назад плиты сблизились полностью, образовав зону коллизии. Один из возможных механизмов закрытия океанического окна - поддвиг верхних горизонтов субокеанической литосферы под корово-мантийные пластины по пологим поверхностям срыва (несубдукционный вариант), одной из которых является раздел Мохо.

На рубеже 2.05-2.10 млрд лет назад начался раздвиг Западной и Восточной микроплит УЩ, который устанавливается тектонофизическими данными по полям субширотного растяжения земной коры. Во время раздвига 2.05-2.10 млрд лет назад эманации и растворы получили возможность подъема в верхнюю кору, стимулируя процессы палингенеза (новоукраинские и кировоградские граниты), а при повторном раздвиге 1.75 млрд лет назад в верхнюю кору интрудировала магма основного и кислого состава (плутон габбро-анортозитов и рапакиви). Зона раздвига совпала с бывшим коллизионным швом и стала местом формирования межрегиональной шовной зоны Херсон - Смоленск, протягивающейся субмеридионально через всю Восточно-Европейскую платформу.

Ключевые слова: геодинамика, полевая тектонофизика, микроплита, транспрессия, транстенсия, напряжения, деформации, зеркало скольжения.

\section{1. ВВЕДЕНИЕ}

Применение комплексного подхода, объединяющего кинематический и структурно-парагенетический методы полевой тектонофизики [Gintov, 2005; Gintov et al., 2008], позволяет строить непрерывную временную развертку напряженно-деформированных состояний (НДС) и деформационных режимов (ДР) изучаемых районов от времени литификации осадочно-вулканогенных толщ до завершения орогенического процесса.

Методом структурных парагенезисов (СПМТ) изучается планетарная трещиноватость (на основании чего определяется положение палеооси вращения Земли), доскладчатые фазы тектонических деформаций и посторогенные деформации [Gintov, 2005].

Кинематическим методом (КМТ) исследуются тектонические деформации, сопровождающие орогенический процесс, заметные перемещения горных пород и сейсмические явления [Rebetsky, 2002].

Материалы комплексирования тектонофизических методов позволяют изучать последовательность накладывающихся друг на друга деформаций горных пород, а в сочетании с данными стратиграфии и петрологии строить геохронологические шкалы деформационных процессов [Gintov, 2005; Murovskaya, 2012]. Получение непрерывной последовательности НДС и ДР позволяет проконтролировать уже известные геодинами- ческие построения и откорректировать геодинамические модели.

Примером может служить изучение НДС и ДР в альпийском структурном этаже Западного Горного Крыма и в докембрийских комплексах центральной части Украинского щита.

\section{2. ЗАПАДНЫЙ ГОРНЫЙ КРЫМ (ЗГК)}

На площади около 4000 км² $^{2}$ измерено более 2000 тектонических зеркал с кинематическими индикаторами и более 600 трещин без таковых.

С использованием СПМТ изучались хрупкие трещины без борозд скольжения и, отдельно, плоскости тектонических зеркал. Трещины были измерены в породах возрастного диапазона от неогена до верхнего мела, что позволило охарактеризовать наиболее ранние поля напряжений, действовавшие в период литификации осадков в соответствующие периоды альпийского тектогенеза.

Изучение плоскостей зеркал скольжения СПМТ (рис. 1) дало возможность определить основные разрывы, по которым осуществляется деформация, и поля напряжений, действовавшие в период их формирования. В количественном отношении доминируют крутопадающие зеркала (75 \% всех плоскостей) следую- 

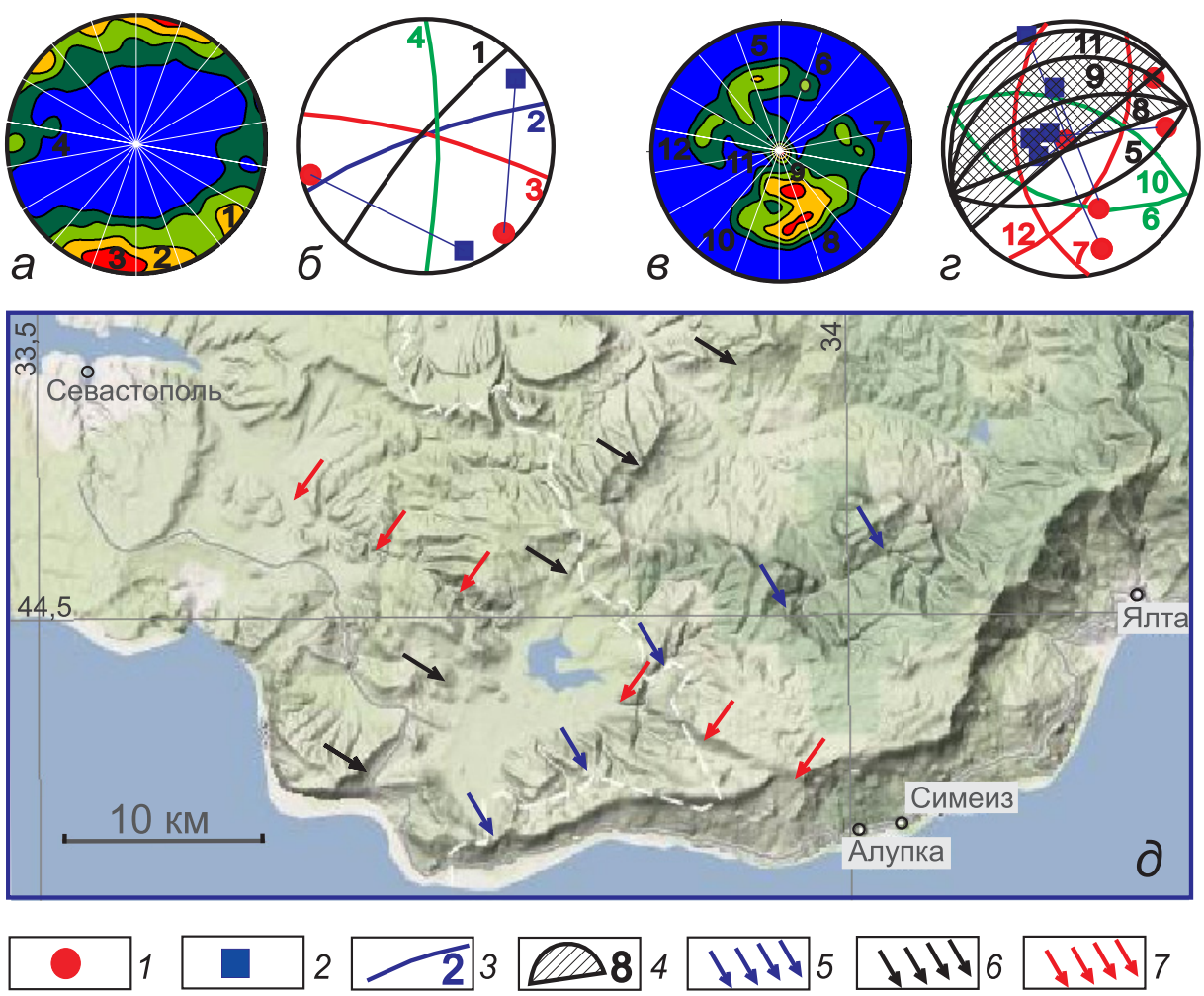

Рис. 1. Стереограммы (здесь и далее верхняя полусфера, проекция Вульфа): концентрации полюсов (a) и плоскостей (б) тектонических зеркал с углами падения $>60^{\circ}, \mathrm{n}=1654$; полюсов (в) и плоскостей (2) тектонических зеркал с углами $<60^{\circ}$, n=500; сечение изолиний 20 \%; $\partial$ - карта 3D-рельефа Западного Горного Крыма.

Положение главных осей нормальных напряжений на стереограммах: 1 - сжатия, 2 - растяжения, 3 - плоскости тектонических зеркал и их номера на стереограммах (б) и (2), соответствующие максимумам и их номерам на стереограммах (a) и (в); 4 - положение плоскостей зеркал северо-восточной ориентировки и юго-восточного падения; 5 - Димерджинская зона разломов, сопоставимая по ориентировке с плоскостью 2 на стереограмме (б); 6 - Ласпинская зона разломов (плоскость 1 на стереограмме (б)); 7 - Чернореченская зона разломов (плоскость 3 на стереограмме (б)).

Fig. 1. Stereograms (the upper hemisphere, Wolf projection here and below): concentrations of poles ( $a$ ) and planes ( 6 ) of tectonic mirrors with dip angles above $60^{\circ}, \mathrm{n}=1654$; concentraitons of poles (b) and planes (2) of tectonic mirrors angles below $60^{\circ}$, $\mathrm{n}=500$; $20 \%$ isolines cross-section; $\partial-$ a map of 3D relief of the Western Mountainous Crimea.

Positions of principal axes of normal stresses in stereograms: 1 - compression, 2 - extension, 3 - planes of tectonic mirrors and their numbers in stereograms (б) and (2), corresponding to maxima and their numbers on stereograms (a) and (b); 4 - positions of mirror planes with NE orientation and SE dip; 5 - Dimerdzhinsky fault zone comparable in orientation with Plane 2 in stereogram 2 (б); 6 - Laspinsky fault zone (Plane 1 in stereogram (б)); 7 - Chernorechensky fault zone (Plane 3 in stereogram (б)).

щих азимутов простирания (рис. 1, a): СВ 30-50 (максимум 1), СВ 60-80 (максимум 2), С3 275-295 (максимум 3) и С 350-10 (максимум 4). На рис. 1, a-2, показаны плоскости, соответствующие пикам концентрации полюсов тектонических зеркал, и поля напряжений, в которых они были заложены. На карте 3Dрельефа (рис. 1, д) отчетливо выделяются три линейные зоны, ориентировки которых соответствуют ориентировкам преобладающих крутопадающих тектонических зеркал. Северо-западные разрывы преобладают в западной части территории, и самым ярким представителем этой системы является Чернореченская зона разломов; северо-восточные разрывы преобладают в центральной и юго-восточной части и сконцентрированы в районе Главной гряды и ее южного и северного склонов [Murovskaya, 2012]. Типичными представителями этих разрывов являются Димерджинская и Ласпинская зоны разломов.

Пологопадающие зеркала развиты существенно меньше и составляют 25 \% от общего количества. Они ориентированы, как правило, в направлении СВ 30-85 с падением в обе стороны. В среднем, зеркала с юговосточным падением более пологие, чем падающие на северо-запад, и их больше в количественном отношении (60 \% против 40 \%) (рис. 1, в, г). Максимуму 11 соответствует группа практически горизонтальных плоскостей, по которым происходили подвижки по направлению ЮВ 130-170.

Для выяснения вопроса о возрасте тектонических зеркал были сопоставлены ориентировки крутопадаю- 

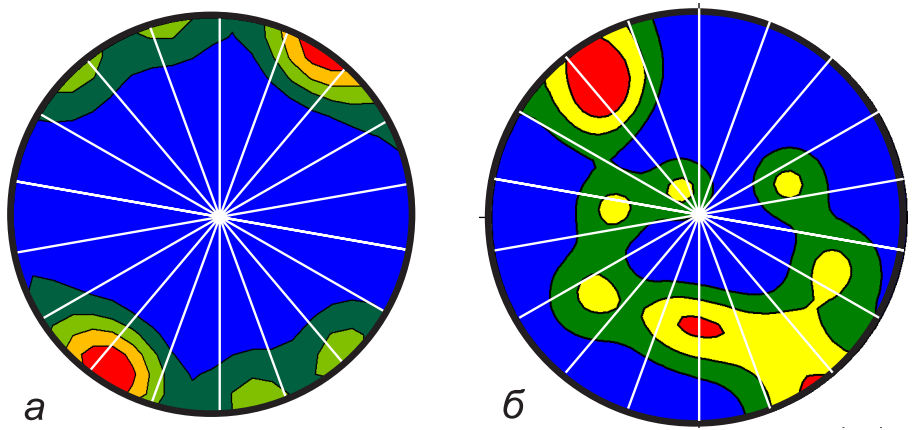

Рис. 2. Стереограммы полюсов: $a$ - трещин в породах неогена, n=621; б - нодальных плоскостей очагов землетрясений, n=16, по [Pustovitenko, 2002].

Fig. 2. Stereograms of poles: $a$ - fractures in the Neogenic rocks, $n=621 ; \sigma-$ nodal planes of earthquake foci, $n=16$ (from [Pustovitenko, 2002]).

щих зеркал с таковыми для разрывов неоген-четвертичного возраста и нодальных плоскостей механизмов очагов восьми наиболее сильных крымских землетрясений (рис. 2).

Среди трещин в породах неогена и тектонических зеркал существенно преобладают крутопадающие плоскости (95 \% и 75 \% соответственно). Среди нодальных плоскостей крутопадающие и наклонные поверхности представлены в примерно равных пропорциях. Ориентация крутопадающих тектонических зеркал сопоставима с ориентацией трещин в породах неогена (рис. 2, a), то есть возраст образования плоскостей зеркал - ранний-средний миоцен. Ориентация пологих тектонических разрывов сопоставима с ориентацией пологих нодальных плоскостей в механизмах очагов (рис. 2, б).

С помощью КМТ изучались тектонические зеркала с бороздами скольжения и нодальные плоскости механизмов очагов землетрясений. Обработка и интерпретация кинематических данных производилась методом правой дигетры и ротационной оптимизации с использованием программы Win Tensor [Devlaux, Sperner, 2003].

Уже при обследовании обнажений было осуществлено предварительное разделение разрывных нарушений на однородные подгруппы, а по взаиморасположению борозд на одном зеркале определялся относительный возраст фаз деформации. Установлена последовательность образования борозд: сдвиговые - взбросовые - сбросовые.

Анализ зеркал с бороздами позволил выделить 61 оптимизированный объем в породах таврической серии, средней и верхней юры, мела, палеогена и неогена, в которых смещения по плоскостям трещин в подавляющем большинстве случаев отражают альпийский этап орогенеза.

Понятие «оптимизированный объем» предлагается использовать вместо введенного О.И. Гущенко [Gushchenko, 1979] понятия «однородно-деформированный объем (массив)», которое в практике полевой тектонофизики использовать практически невозможно. Оптимизированный - это такой локализованный массив горных пород - обнажение, часть обнажения, группа расположенных рядом обнажений, в котором фиксируется не менее 10 зеркал с бороздами скольжения и который может быть уменьшен по результатам интерпретации путем отсечения зеркал, расположенных на его периферии и не влияющих принципиально на первое поле напряжений, полученное по максимальному количеству векторов подвижек. Для этого тектонофизические измерения выполняются с применением GPS и с зарисовкой местоположения всех зеркал скольжения.

По каждому оптимизированному объему горных пород получено от одного до четырех положений главных осей, отвечающих различным деформационным режимам и фазам деформации. Все восстановленные поля напряжений относятся к сдвиговому, сбросовому или взбросовому типу. Гистограмма (рис. 3)

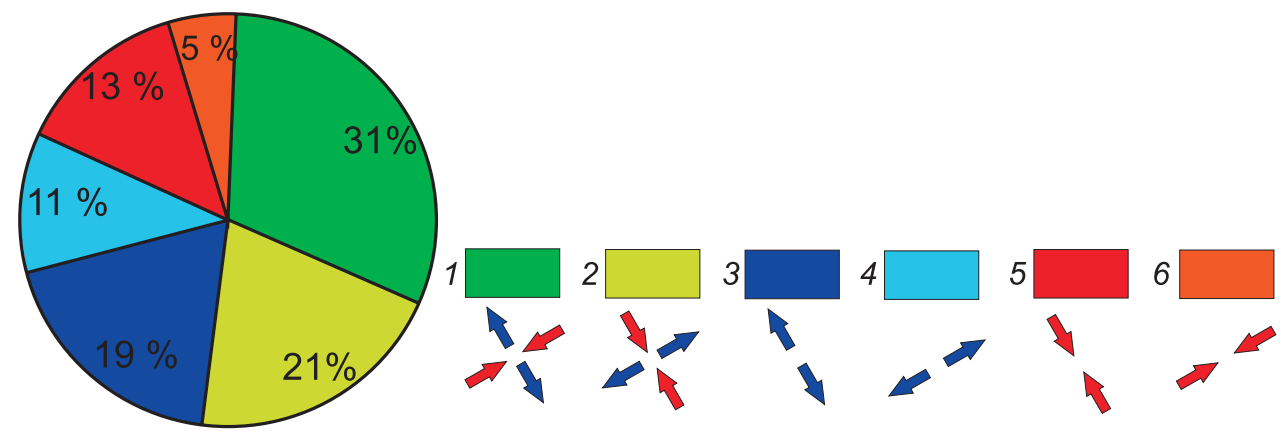

Рис. 3. Гистограмма типов полей напряжений: 1 - сдвиговый тип № $1 ; 2$ - сдвиговый тип № 2; 3 - сбросовый тип № 1 ; 4 сбросовый тип № 2; 5 - взбросовый тип № 1; 6 - взбросовый тип № 2.

Fig. 3. Histogram of stress field types: 1 - shift type $1 ; 2$ - shift type 2 ; 3 - normal type 1 ; 4 - normal type 2; 5 - reverse thrust type $1 ; 6$ - reverse thrust type 2 . 


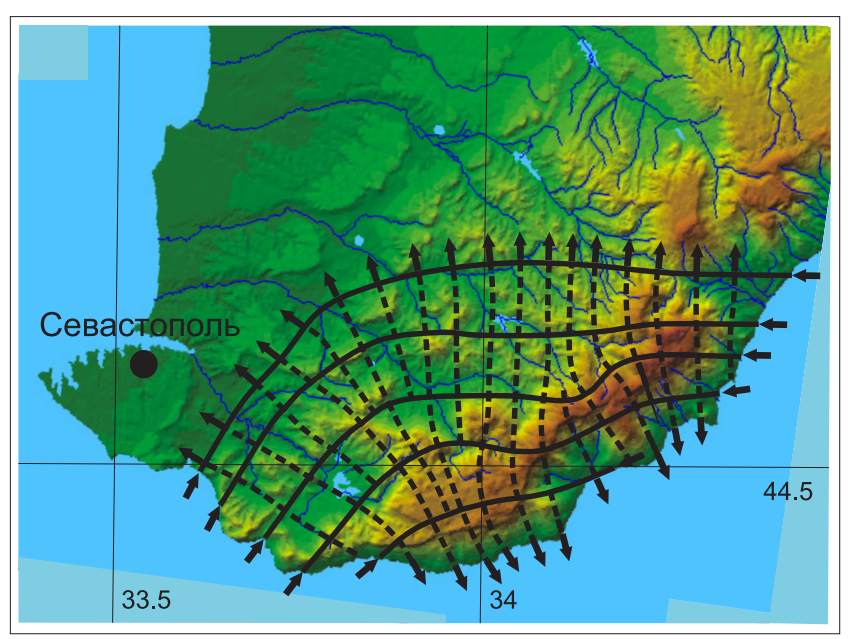

a

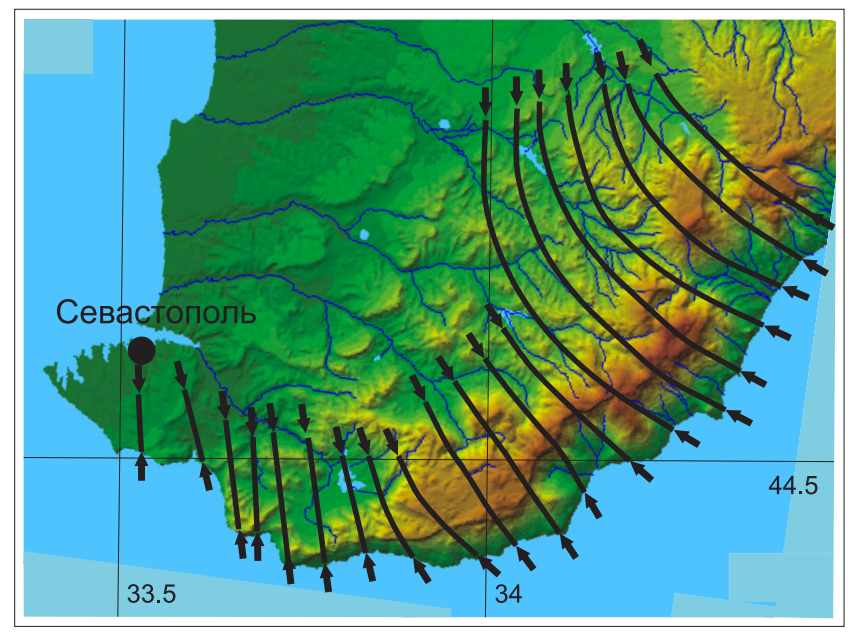

8

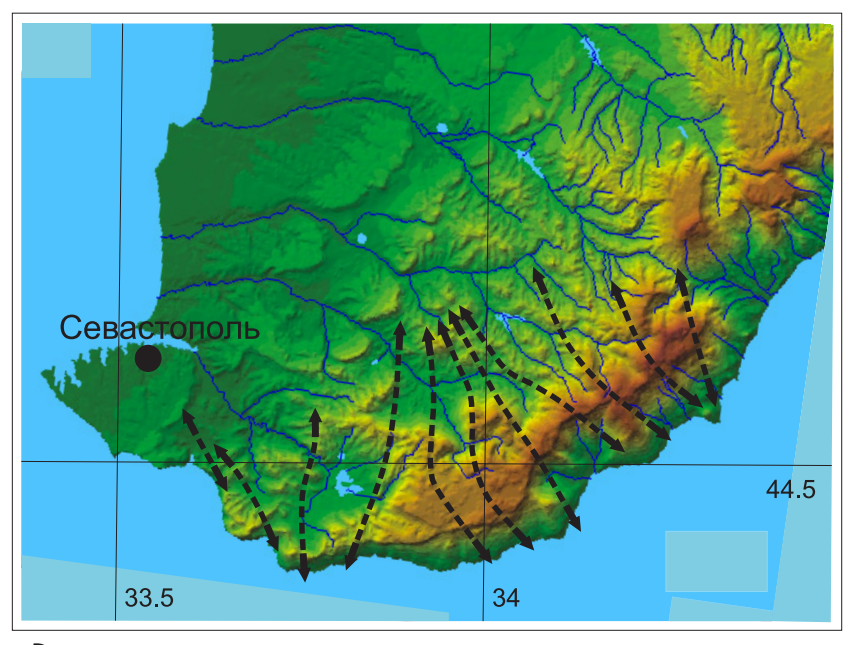

$\partial$

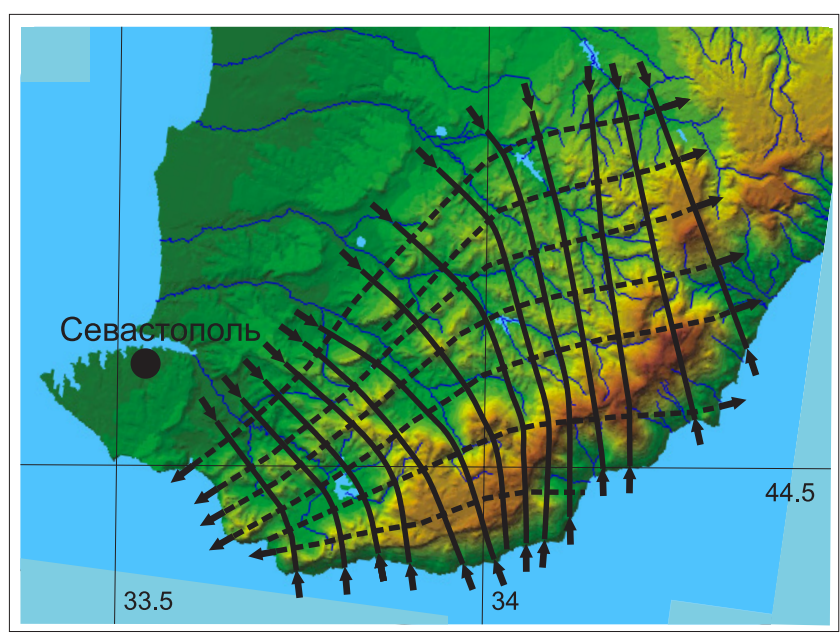

$\sigma$

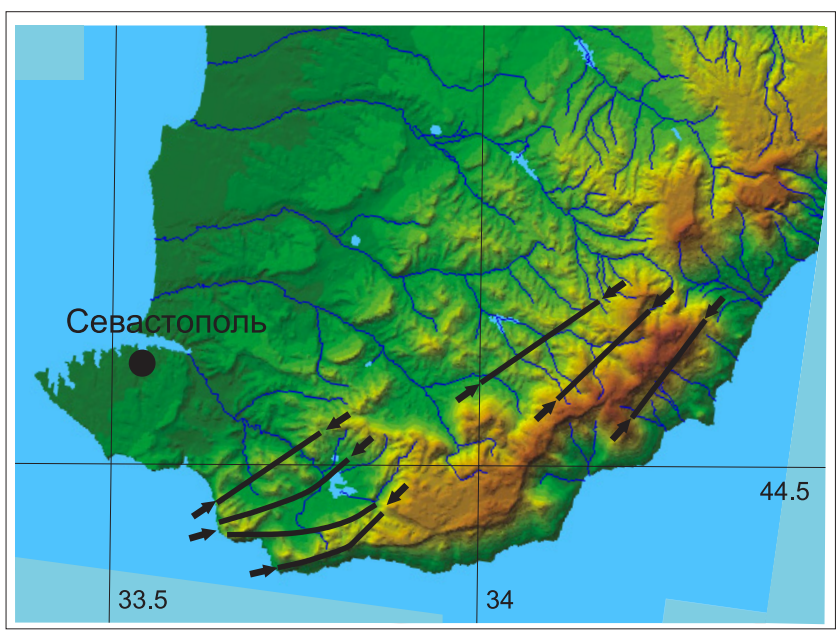

2

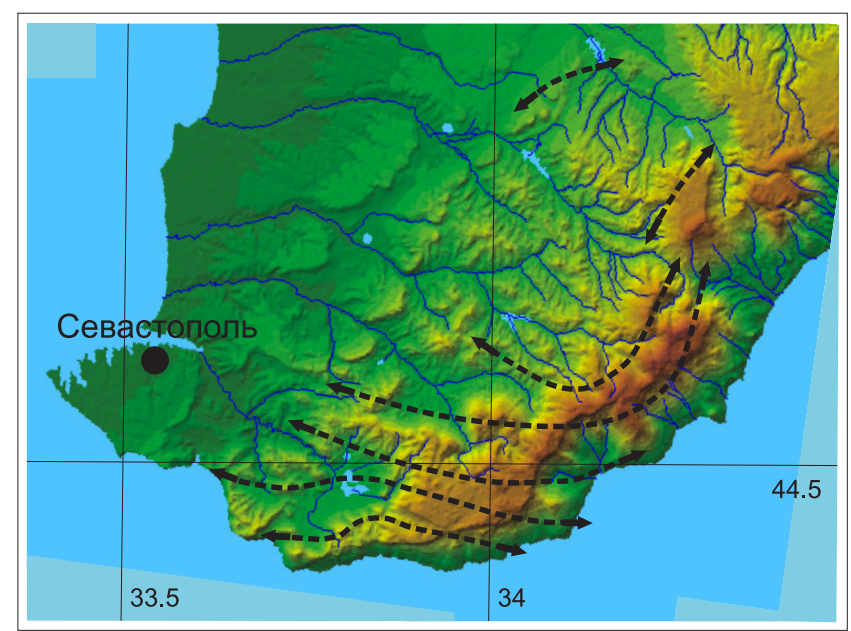

e

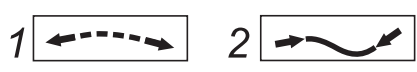

Рис. 4. Траектории осей главных нормальных напряжений для полей: $a$, $\sigma$ - сдвигового типа; в, г - взбросового типа; $\partial, e-$ сбросового типа.

1 - оси растяжения, 2 - оси сжатия.

Fig. 4. Trajectories of principal normal stress axes for the fields by types: $a$, $\sigma$ - shift; $в, 2$ - reverse thrust; $\partial, e$ - normal.

1 - extension axes; 2 - compression axes. 

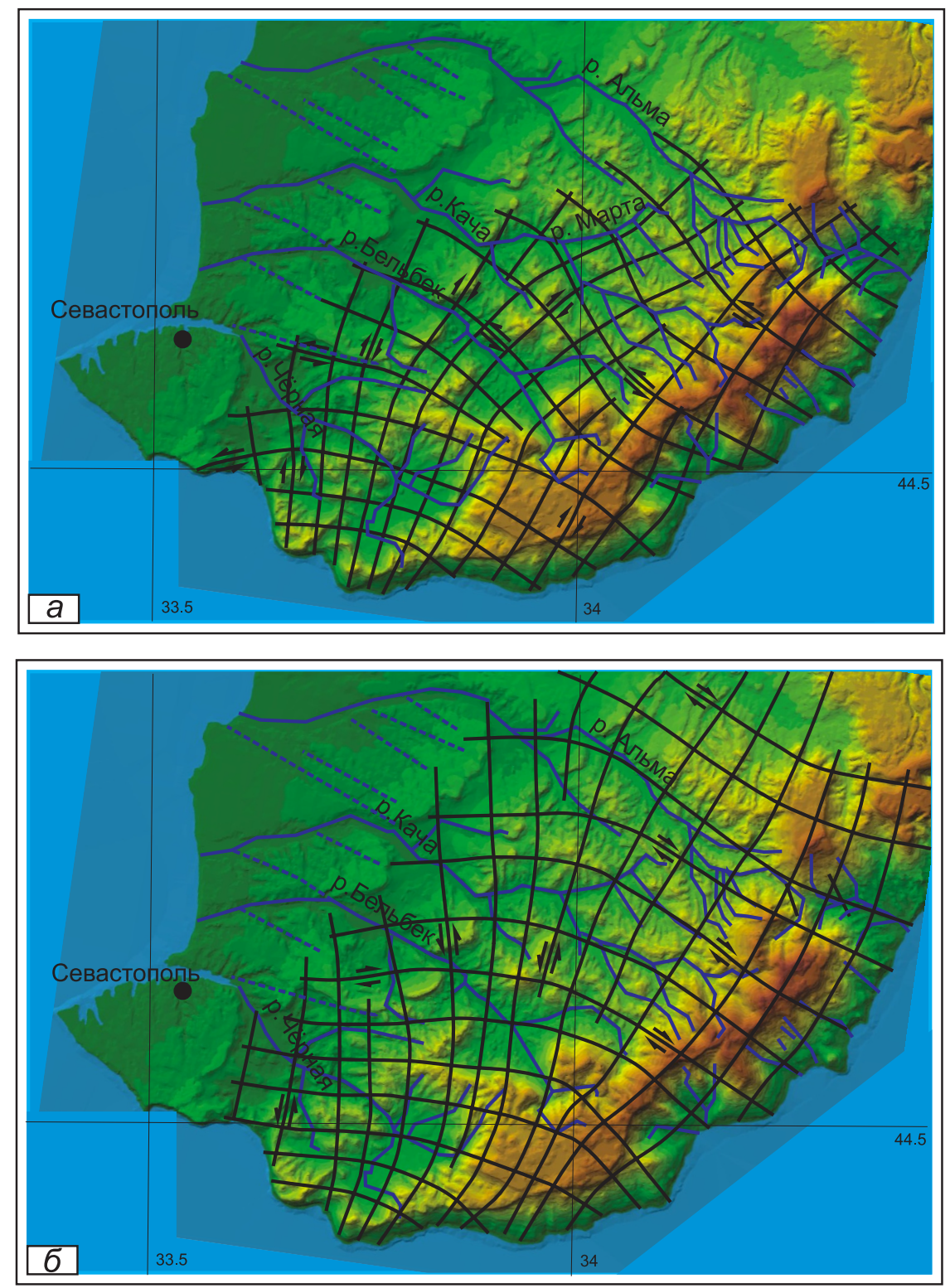

Рис. 5. Траектории максимальных касательных напряжений для полей сдвигового типа: $a$ - поле № $1 ; \sigma$ - поле № 2 .

Стрелки указывают направления возможных сдвиговых перемещений. Пунктиром показаны палеодолины по геоморфологическим данным.

Fig. 5. Trajectories of maximum tangential stresses for shear fields: $a$ - field $1 ; \sigma$ - field 2 .

Arrows show possible shift directions. Dotted lines show paleovalleys according to geomorphological data.

обобщает результаты количественного распределения тектонических зеркал по типам полей напряжений.

Наиболее проявлены сдвиговые поля с ориентировкой оси сжатия вдоль простирания Горного Крыма. Вторыми по представительности являются сдвиговые поля с осями сжатия, ориентированными вкрест простирания Горного Крыма. Достаточно широко развиты поля сбросового типа с северо-западной ориентировкой действующей оси растяжения. Следующими по представительности являются поля взбросового типа с осями сжатия, ориентированными с северо-запада на юго-восток или с севера на юг. Для всех полей дейст- вующая ось, которая определялась в соответствии с коэффициентом R [Devlaux, Sperner, 2003], а также с учетом геологических данных (ориентировка бассейна осадконакопления, наличие или отсутствие структур растяжения и др.), является субгоризонтальной, а ее ориентировка так или иначе связана с генеральным простиранием ЗГК.

Достаточно густая сеть наблюдений позволила построить карты изолиний главных нормальных (рис. 4) и касательных (рис. 5) напряжений для каждой из выделенных групп полей напряжений.

Рисунки траекторий для обоих сдвиговых полей во 


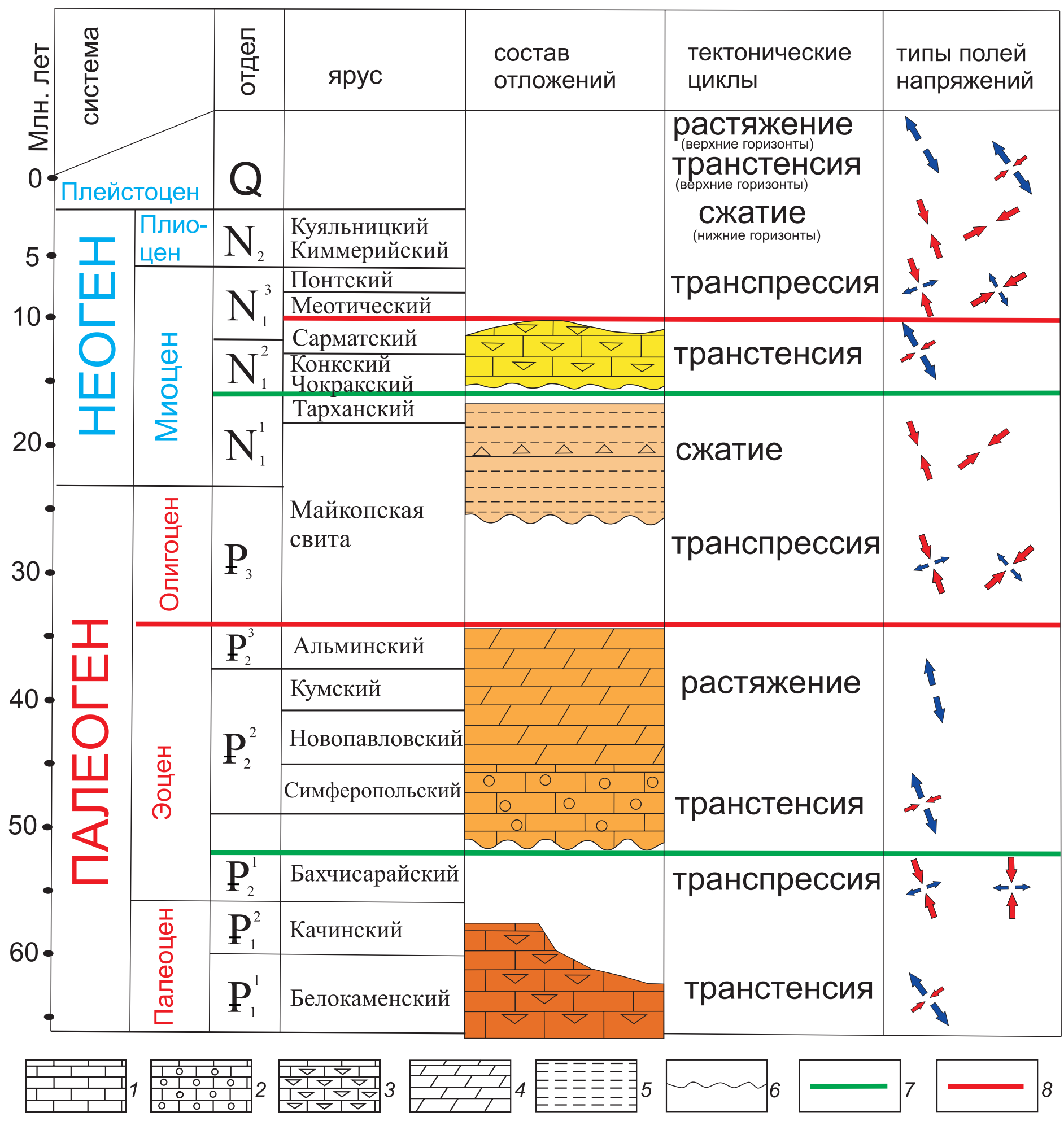

Рис. 6. Тектонические циклы, по [Volfman, 2008], и типы полей напряжений.

1 - известняк; 2 - нумулитовый известняк; 3 - детритусовый известняк; 4 - мергель; 5 - глина; 6 - перерыв в осадконакоплении; 7 - начало погружения; 8 - начало орогенеза. Красные стрелки - оси сжатия, синие - оси растяжения. Стрелки большего размера обозначают действующую ось.

Fig. 6. Tectonic cycles (from [Volfman, 2008]) and stress field types.

1 - limestone; 2 - numulite limestone; 3 - detrital limestone; 4 - marl; 5 - clay; 6 - break in sedimentation; 7 - subduction start; 8 - orogeny start. Stress axes are shown by arrows: red - compression, blue - extension. Big arrows show the current axes. 


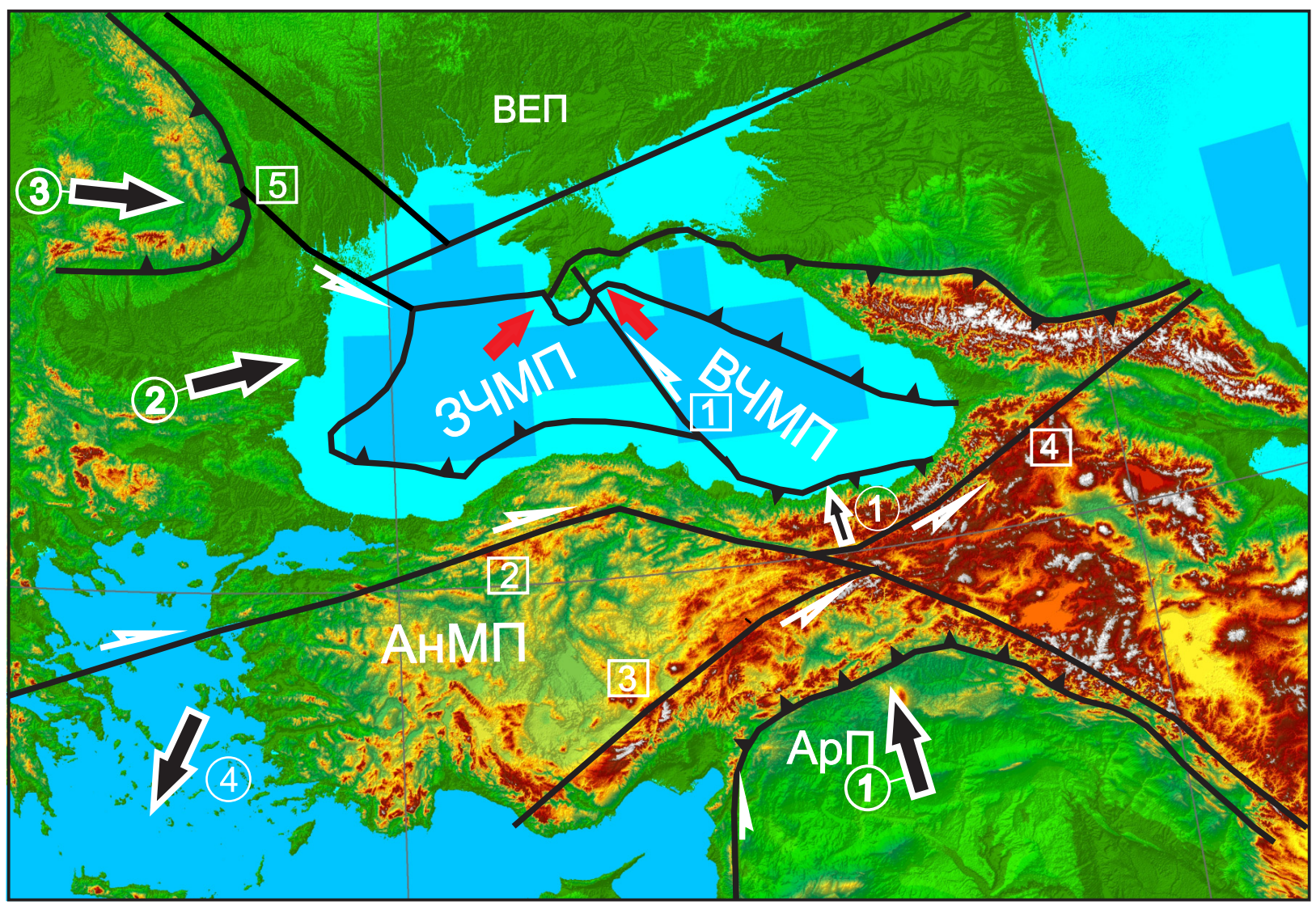

Рис. 7. Схема геодинамики Восточного Средиземноморья, по [Patalaha et al., 2003], с учетом тектонофизических данных по Горному Крыму, полученных авторами.

Направления воздействия плит на Восточно- и Западночерноморскую микроплиты (черные стрелки и цифры в кружках): 1 - Аравийской, 2 - Адриатической, 3 - Паннонской, 4 - Эллинско-Кипрской островной дуги. Зоны сдвигов (цифры в квадратах и белые стрелки): 1 - Салгиро-Октябрьская, 2 - Северо-Анатолийская, 3 - Восточно-Анатолийская, 4 - Северо-восточно-Анатолийская, 5 - юго-восточная часть зоны Тейссейра-Торнквиста. Буквенные обозначения: АнМП - Анатолийская микроплита, АрП - Аравийская плита, ВЧМП - Восточно-Черноморская микроплита, ЗЧМП - Западно-Черноморская микроплита, ВЕП - Восточно-Европейская плита. Красные стрелки обозначают направления давления ВЧМП и ЗЧМП на Крымский полуостров. Черные линии с навесными знаками обозначают надвиги и направление падения их плоскостей.

Fig. 7. The scheme of geodynamics of Eastern Mediterranean region (from [Patalaha et al., 2003]), including tectonophysical data obtained by the authors for Mountainous Crimea.

Black arrows and numbers in circles show impact on the Eastern and Western Black Sea microplates from the Arabian (1), Adriatic (2), and Pannonian (3) plates, and the Hellenic-Cyprus island arc (4). Shear zones (white arrows and numbers in boxes): 1 - Salgiro-Oktyabrskaya; 2 - North Anatolian; 3 - East Anatolian; 4 - North-Eastern Anatolian; 5 - south-eastern part of Teisseyre-Tornquist zone. Letters: AнMП - Anatolian microplate, АрП - Arabian Plate, ВЧМП - Eastern Black Sea microplate, ЗЧМП - Western Black Sea microplate, ВЕП - East European plate. Red arrows show directions of pressure from ВЧМП and ЗЧМП to the Crimean peninsula. Black lines with overhead signs show thrusts and their dip direction.

многом подобны. Оси сжатия и растяжения просто меняются местами, а траектории максимальных касательных напряжений остаются в одном положении.

Основным отличием систем траекторий для двух сдвиговых полей являются направления сдвиговых перемещений вдоль них. Например, в поле первого типа по северо-западным направлениям могут осуществляться левосдвиговые перемещения, а в поле второго типа по тем же направлениям будут реализоваться правые сдвиги. Иногда правые и левые сдвиги фиксируются на одних и тех же тектонических зеркалах в разной временной последовательности. Оба поля ре- конструированы для трещин в сарматских отложениях и, следовательно, существовали в постсарматское время. В связи с этим мы полагаем, что оба сдвиговых поля напряжений близки по возрасту. Можно даже сказать, что они квазиодновозрастны и, возможно, несколько раз сменяли друг друга в течение всего неотектонического периода. Такие поля мы называем инверсионными, а соответствующие им перемещения реверсными. Полагаем, что реверсный характер перемещений отражает импульсный характер тектонического процесса и нуждается в отдельном рассмотрении. 
Для сдвиговых полей наблюдается очевидное совпадение многих участков речной сети и обрывистых склонов гряд Горного Крыма с траекториями максимальных касательных напряжений (рис. 5). Это указывает на определяющий характер сдвиговых зон для формирования гидросети и южных склонов крымских гряд. Если учитывать, что большинство речных долин района заложены вдоль разломов, активизированных на послесарматском отрезке развития, то можно сделать вывод о преобладающем послесарматском возрасте борозд и штрихов на зеркалах, образованных в зонах разломов.

Поля напряжений были сопоставлены с циклами трансгрессий-регрессий для Крымского полуострова и Причерноморья [Volfman, 2008]. Начиная с палеоцена было выделено 11 обобщенных полей напряжений, которые отражают эволюцию земной коры региона в альпийском тектоническом цикле (рис. 6). Большинство фаз деформации характеризуются горизонтальным положением плоскости $\sigma_{1}, \sigma_{3}$ и соответствуют режимам транспрессии и транстенсии.

Режим сжатия (ранний миоцен и средний плиоцен) и растяжения (средний эоцен и плейстоцен) с преобладанием, соответственно, взбросовых и сбросовых перемещений характерен для достаточно коротких, но ярких горообразовательных процессов на общем фоне субгоризонтальных сдвигов.

Динамика Горного Крыма, относящегося к кавказскому сегменту альпийского орогенного пояса, рассмотрена в общем контексте коллизионного взаимодействия Евразийской и Аравийской плит и ряда микроплит, в том числе Восточно-Черноморской (ВЧМП) и Западно-Черноморской (ЗЧМП) (рис. 7). Западное ограничение ВЧМП, а также тектоническая роль ВЧМП и ЗЧМП являются дискуссионными. Детальная информация о напряженно-деформированном состоянии Горного Крыма позволяет внести уточнения в кинематику ВЧМП и ЗЧМП.

Согласно результатам интерпретации аномалий геоида, ЗГК находится в состоянии регионального сжатия [Dovbnich, Demianets, 2009]. При этом, по результатам тектонофизических исследований, присутствует как поперечное сжатие в северо-западном-юговосточном направлении, так и продольное в северовосточном и юго-западном направлениях и соответствующие им сдвиговые поля. Эти закономерности можно связать с преимущественным давлением ВЧМП в восточной части ЗГК до меридиана Ялты и ЗЧМП - в западной части ЗГК. В земной коре на меридиане Ялты суммируется давление ВЧМП и ЗЧМП с юго-востока и юго-запада соответственно. Характерно, что к Ялтинскому сектору Крымской сейсмогенной зоны относится и наибольшее количество землетрясений, зафиксированных в ней [Pustovitenko, 2002].

Таким образом, приходим к заключению, что под нажимом Аравийской плиты ВЧМП движется на северо-запад и оказывает давление на Восточный и Цен- тральный Горный Крым. ЗЧМП передает давление на ЗГК с запада и юго-запада, со стороны граничащих с ней Паннонской и Адриатической микроплит (рис. 7). Кора ЗГК, и по тектонофизическим данным, и по результатам интерпретации аномалий геоида, в основной своей части находится в состоянии регионального сжатия, обусловленного кинематикой этих микроплит. Давление микроплит приводит к интенсивному воздыманию Крымских гор, а режим сжатия трансформируется в сдвиговый.

Повсеместно фиксируемое в пределах ЗГК напряженно-деформированное состояние северо-западные и юго-восточные растяжения относятся только к поверхностным слоям земной коры вследствие их поднятия и изгиба. Естественной моделью такого процесса может служить развал орогена - обрушение яйлинских верхнеюрских известняковых пластин по системе крутопадающих сбросов и сползание их фрагментов в сторону моря.

\section{3. УКРАИНСКИЙ ЩИТ (ЦЕНТРАЛЬНАЯ ЧАСТЬ - ИНГУЛЬСКИЙ МЕГАБЛОК)}

На рис. 8 условными цветами показана мегаблоковая делимость УЩ, а на врезке - его положение в пределах сарматского сегмента Восточно-Европейского кратона, представленного, по [Bogdanova et al., 1996], тремя крупными сегментами - Фенноскандией, ВолгоУралией и Сарматией.

Протерозойский Ингульский мегаблок (ИМБ) УЩ расположен между архейскими Бугским, Росинским (на западе) и Среднеприднепровским (на востоке) мегаблоками, испытывавшими неоднократные, преимущественно тангенциальные, перемещения. С геодинамической точки зрения, они являются микроплитами (Западной и Восточной, соответственно), разделенными дивергентно-конвергентной областью, которая и называется Ингульским мегаблоком. На УЩ нет более деформированного участка литосферы, чем эта область, что подтверждается не только тектонофизическими, но и сейсмотомографическими данными (рис. 9, a).

Докембрийские комплексы ИМБ изучались преимущественно структурно-парагенетическим методом (рис. 9, б, в), так как зеркала скольжения с кинематическими индикаторами сохранились в небольшом количестве и отражают только самые поздние движения субплатформенного и платформенного периодов (рис. 9 , г). При изучении архейских и раннепротерозойских тектонических этапов широко использовались особенности пластической деформации горных пород (рис. 9, в) с помощью приемов, изложенных в работах [Gintov, Isai, 1988; Gintov, 2005].

По материалам тектонофизических исследований составлена структурно-тектонофизическая карта района (рис. 10), а на ее основе - геологическая карта 

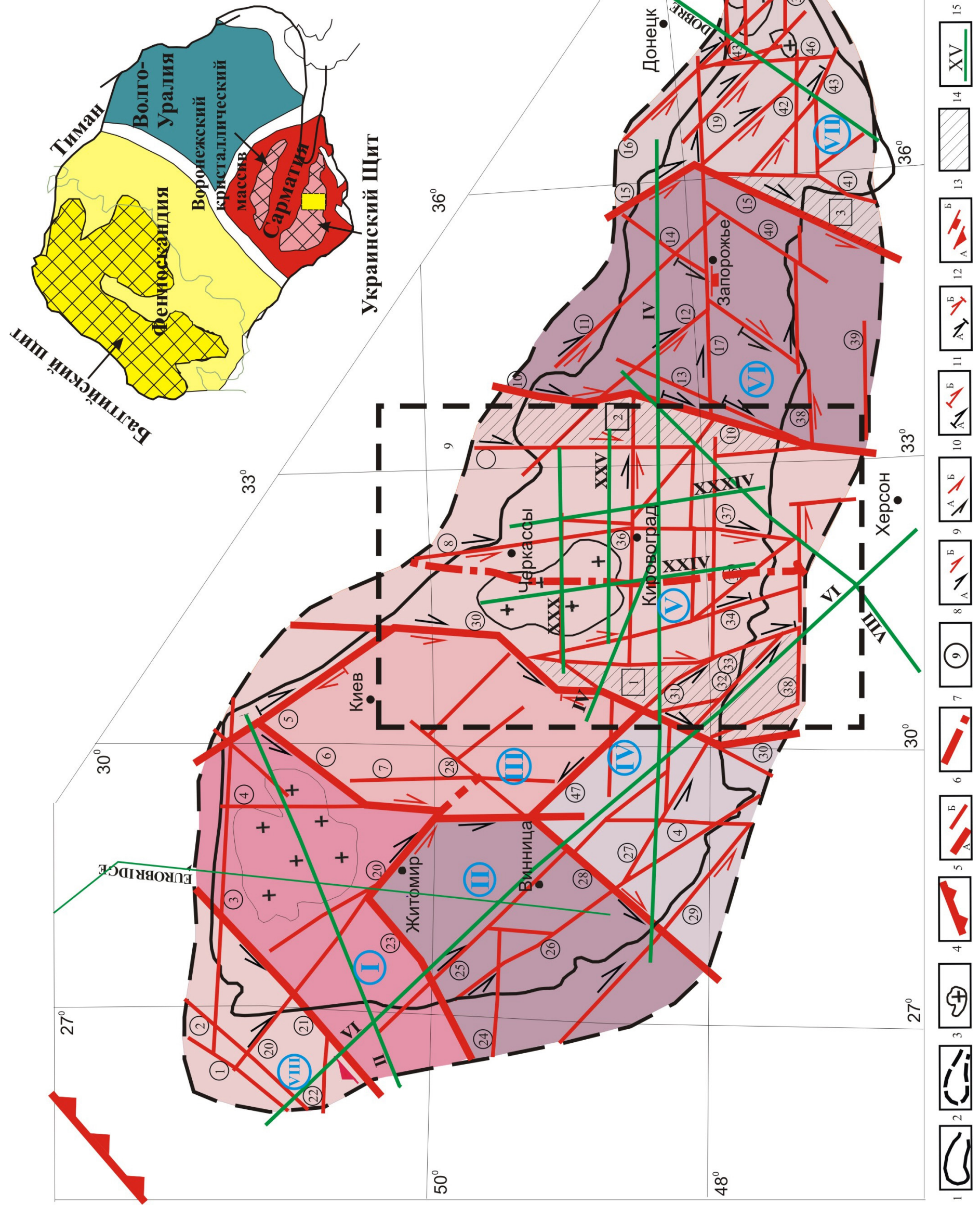
Рис. 8. Схема разломно-блоковой структуры УЩ [Gintov, 2005; Gintov, Pashkevich, 2010; Gintov, Mychak, 2011].

1 - контур обнаженной части щита; 2 - контур склонов щита, в пределах которых прослеживаются складчатые и разрывные структуры докембрийского фундамента по геофизическим данным; 3 - плутоны и крупные интрузивные массивы гранитоидов; 4 - граница между Сарматией и Фенноскандией; 5 - зоны разломов: А, Б - меж- и внутримегаблоковые соответственно; 6 - трансрегиональная зона раздвига Херсон-Смоленск; 7 - номера зон разломов, по [Gintov, 2005]; кинематические знаки: 8 - правый сдвиг ( $A$ - во время заложения, 5 во время главной фазы активизации); 9 - левый сдвиг (А и Б - то же, что и в 8); 10 - взбросо-сдвиг (А и $Б$ - то же, что и в 8); 11 - сбрососдвиг (А и Б - то же, что и в 8); 12 - взброс (a) и сброс (б); 13 - шовные зоны (цифры в квадратиках): 1 - Голованевская, 2 - ИнгулецкоКриворожская, 3 - Орехово-Павлоградская; 14 - профили ГСЗ (в том числе и геотраверсы) и их номера; 15 - мегаблоки: I - Волынский, II - Подольский, III - Росинский, IV - Бугский, V - Ингульский, VI - Среднеприднепровский, VII - Приазовский, VIII - BолыноПолесский вулканоплутонический пояс.

Fig. 8. Fault-block structure of the Ukrainian Shield (УЩ) [Gintov, 2005; Gintov, Pashkevich, 2010; Gintov, Mychak, 2011].

1 - contour of the outcropped part of the shield; 2 - contours of the shield's slopes where folded and fault structures of the Precambrian basementcan be traced from geophysical data; 3 - plutons and large intrusive granitoid massifs; 4 - border between Sarmatia and Fennoscandia; 5 - fault zones: A - inter-megablock zones, Б - intra-megablock zones; 6 - transregional zone of the Kherson-Smolensk extension fault; 7 - number of fault zones according to [Gintov, 2005]; kinematic signs: 8 - right shift ( $A$ - during inception, $\overline{-}$ - during the main phase of activation); 9 - left

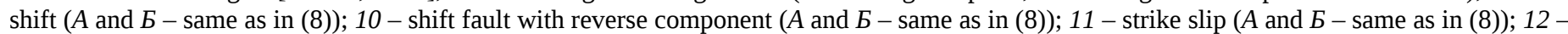
reverse ( $a$ ) and normal faults (б); 13 - suture zones (numbers in boxes): 1 - Golovanevskaya, 2 - Inguletsko-Krivorozhskaya, 3 - OrekhovoPavlogradskaya; 14 - DSS profiles (including geotraverses) and their numbers; 15 - megablocks: I - Volynsky, II - Podolsky, III - Rosinsky, IV Bugsky, V - Ingulsky, VI - Srednepridneprovsky, VII - Priazovsky, VIII - Volyno-Polessky volcano-plutonic belt.

ИМБ (рис. 11). В отличие от обычных геологических карт, на которых зоны разломов изображаются единичными линиями, на представленных картах видно, что зоны разломов - это сложные сдвиговые системы шириной 10-15 км, состоящие из многих зон скалывания, эшелонированных и элементарных сколов.

На рис. 12 и 13 показана примерная геодинамическая схема развития региона в этот период. Предполагается, что Западную и Восточную микроплиты в архее разделяла океаническая или субокеаническая литосфера. На рис. $12, a, 13, a$, отражен гипотетический неоархейский дивергентный этап развития литосферы Ингульского мегаблока, раздвиг Западной и Восточной микроплит и начало отложения на их пассивных окраинах вулканогенно-осадочных образований бугской (на западе) и криворожской (на востоке) серий. Обе серии петрографически различны, отражают состав «материнских» плит: бугская - Западной, а криворожская - Восточной. Кора региона представлена двумя реологически разными горизонтами - верхним жестким и нижним пластичным (рис. 13). Подток снизу астеносферного плюма (рис. 13, a) сопровождался выжиманием океанической литосферы в стороны, что приводило к внедрению ее между литопластинами и раздвигу микроплит (несубдукционный вариант, по [Sizova et al., 2010]). Этот этап не зафиксирован тектонофизическими данными, но предполагается в связи с наличием бугской и криворожской серий, нижний возраст которых около 2.8 млрд лет [Shcherbak, 2005, 2008].

По тектонофизическим данным установлены 13 этапов деформации региона между 2.7 и 1.6 млрд лет назад. Восемь этапов отражают северо-восточное и юго-западное сжатия, остальные - северо-восточное, юго-западное и субширотное растяжение [Gintov, Mychak, 2011].

В соответствии с этими данными, на отрезке 2.72.05-2.10 млрд лет назад начался конвергентный этап развития литосферы Ингульского мегаблока (на рис. 13 он не показан). Регион начал развиваться преимущественно в режиме транспрессии, при котором Западная (гнейсово-гранулитовая и амфиболит-гранитовая) и Восточная (гранит-зеленокаменная) архейские микроплиты УЩ сближались под острым углом (см. рис. 12,6, ). Этот этап фиксируется тектонофизическими данными по образованию правосдвиговых (при сжатии) Первомайской, Западно-Ингулецкой и ряда менее крупных зон разломов (см. рис. 12, б), а также началом складчатости в породах бугской и криворожской серий. Отложение $\geq 2.45$ млрд лет назад в центральной части ИМБ толщи вулканогенно-осадочных пород ингуло-ингулецкой серии [Shcherbak, 2005] свидетельствует о режиме растяжения, прерывавшем режим транспрессии, однако после этого косое сближение микроплит возобновилось.

В период 2.3-2.4 млрд лет назад плиты сблизились полностью, образовав зону коллизии, представлявшую собой зону интенсивного смятия пород бугской, криворожской и ингуло-ингулецкой серий (рис. 13, б). На этом этапе образовались Тальновская и Криворожская правосдвиговые зоны разломов и окончательно сформировалась широкая шовная зона по типу «ультрагорячих орогенов» (УГО) [Chardon et al., 2009], под которой образовался прогиб Мохо. Вертикальные стрелки, направленные вниз, отражают перемещение вещества шовной зоны вниз при боковом сжатии.

Механизм коллизии Западной и Восточной микроплит точно не известен. Один из возможных тектоно- 

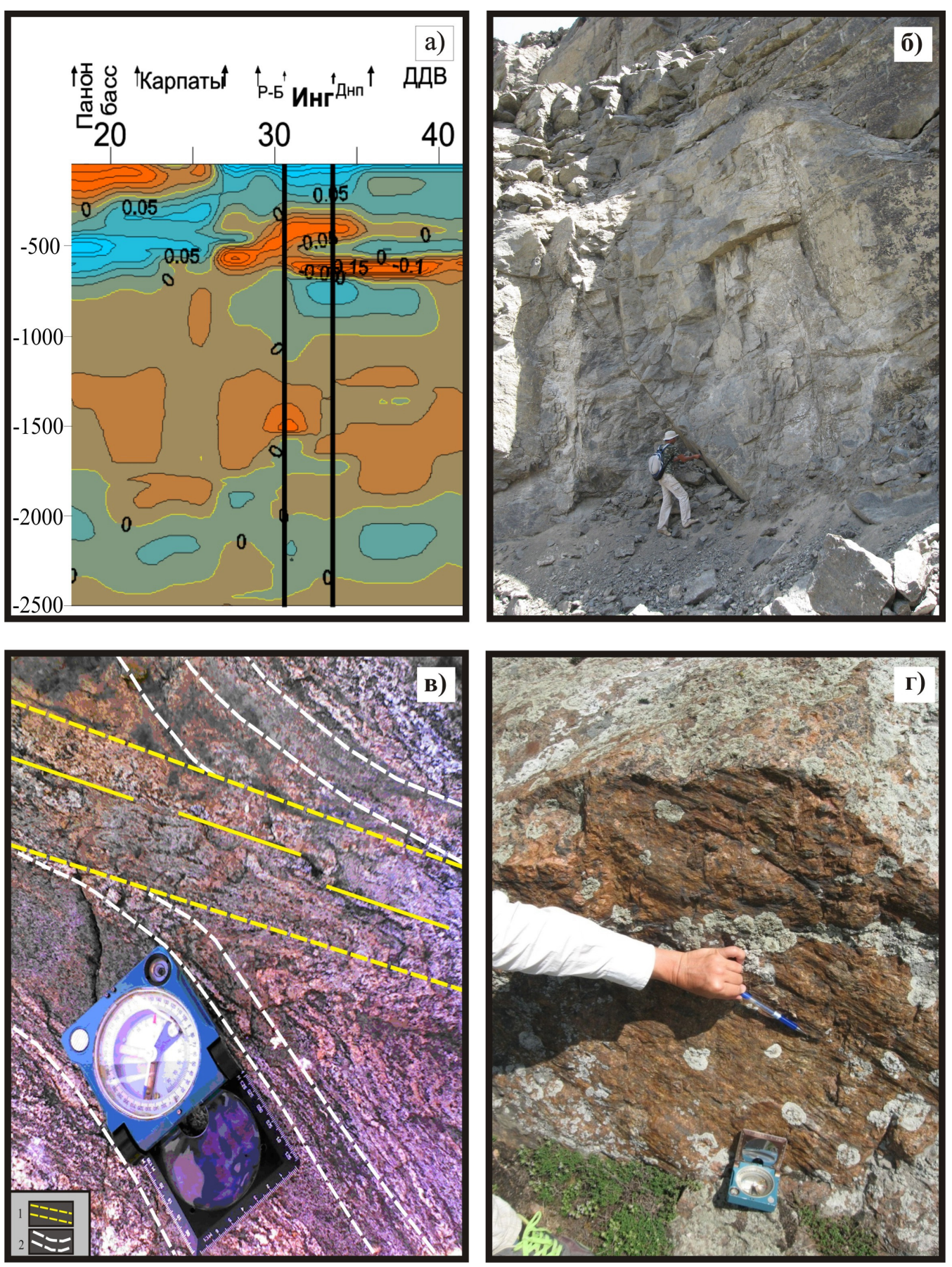

Рис. 9. К методике изучения Ингульского мегаблока: $a$ - проявление мегаблока (выделен жирными вертикальными линиями) в трехмерной Р-скоростной модели мантии Украины (фрагмент широтного вертикального сечения вдоль параллели $48^{\circ}$ с.ш., по [Geyko et al., 2005]).

Скоростная модель представлена в изолиниях невязок (отклонений) скорости относительно обобщенной модели $\mathrm{V}_{\mathrm{p}}$ мантии под территорией Евразии и ее окружения. Горизонтальная шкала - градусы в.д., вертикальная шкала - глубина в км. Буквенные обозначения: Р-Б Росинский и Бугский мегаблоки, Инг - Ингульский мегаблок, Днеп - Среднеприднепровский мегаблок, ДДВ - Днепровско-Донецкая впадина; $\sigma$ - поверхность сброса в Новоукраинском массиве трахитоидных гранитов; в - деформация левого сдвига в мигматитах кировоградского комплекса: 1 - зона элементарного скола, 2 - структуры подворота; 2 - зеркало скольжения в кировоградских гранитах.

Fig. 9. Re the methods of studying the Ingulsky megablock: $a$ - manifestation of the megablock (shown by bold vertical lines) in the 3D P-velocity model of the mantle of Ukraine (a fragment of the latitudinal vertical section along latitude $48^{\circ} \mathrm{N}$, from [Geyko et al., 2005]).

The velocity model is presented in isolines showing deviations of the velocity against the generalized model of $\mathrm{V}_{\mathrm{p}}$ of the mantle beneath the territory of Eurasia and adjacent regions. Horizontal scale - degrees of East longitude; vertical scale - depth (km). Letters: P-Б - Rosinsky and Bugsky megablocks, Инг - Ingulsky megablock, Днеп - Srednepridneprovsky megablock, ДДВ - Dnepr-Don basin; $\sigma$ - surface of the normal fault in the Novoukrainsky massif of trachytoid granites; 8 - deformation of the left-lateral shift in migmatites of the Kirovogradsky complex: 1 - zone of elementary shearing, 2 - roll-up structure; 2 - slikenside in the Kirovogradsky granites. 


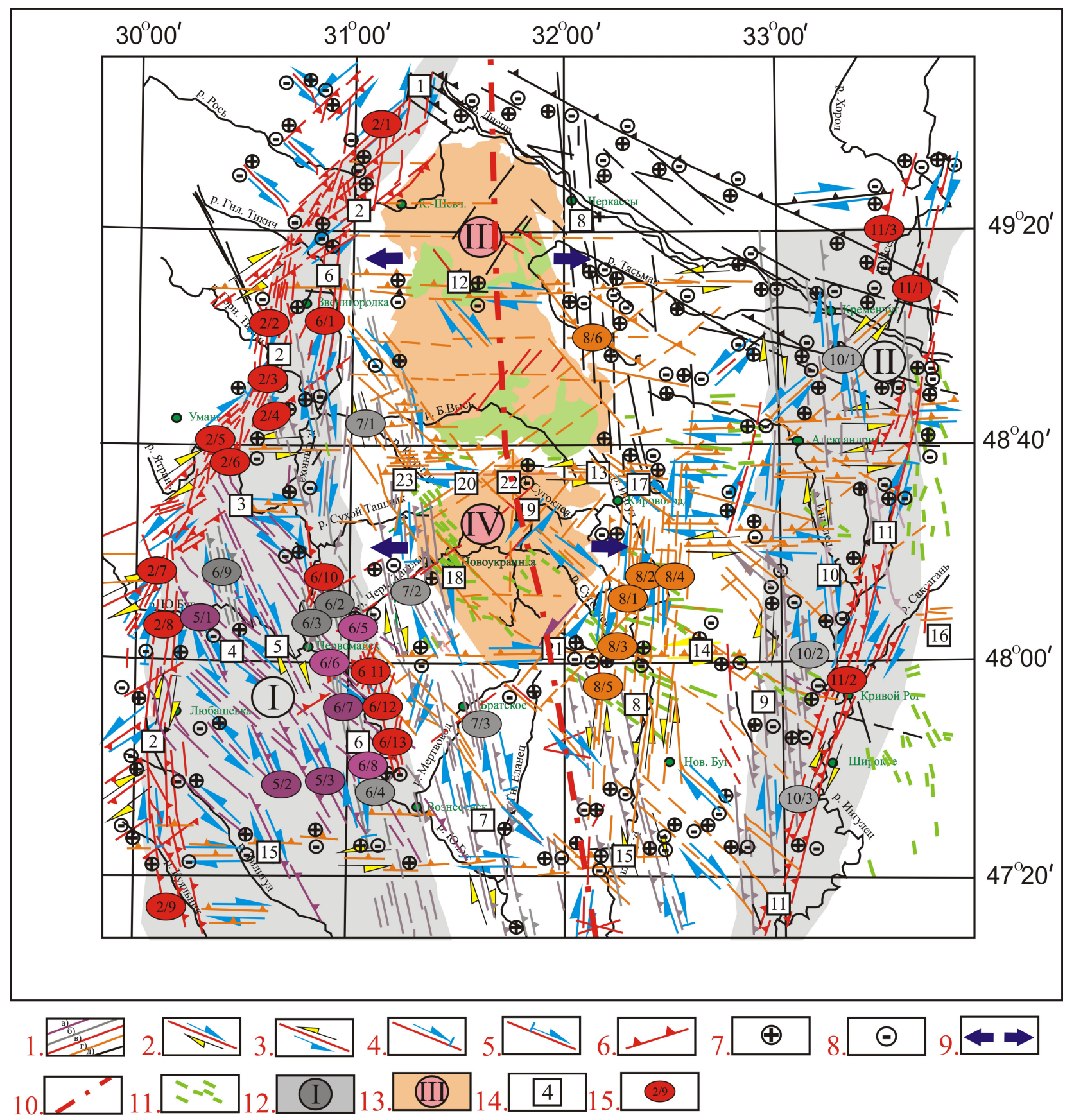

Рис. 10. Структурно-тектонофизическая карта Ингульского мегаблока (по [Gintov, Mychak, 2011]).

1 - эшелонированные и элементарные сколы зон разломов, образовавшиеся в: а - неоархее $\left(\mathrm{AR}_{3}\right)$, 6 - неоархее - раннем протерозое $\left(\mathrm{AR}_{3}-\mathrm{PR}_{1}-\mathrm{I}\right)$, в - начале раннего протерозоя $\left(\mathrm{PR}_{1}-\mathrm{I}\right)$, г - конце раннего протерозоя $\left(\mathrm{PR}_{1}-\mathrm{II}\right)$, д - возраст не известен; кинематические знаки (синие - во время заложения зон разломов, желтые - во время главной фазы активизации); 2 - правый сдвиг; 3 - левый сдвиг; 4 - сбросо-сдвиг; 5 - взбросо-сдвиг; 6 - направление падения; 7 - приподнятое крыло; 8 - опущенное крыло; 9 - направление раздвига центральной части Ингульского мегаблока; 10 - межрегиональная зона раздвига Херсон-Смоленск; 11 - дайки диабазов, габбро-диабазов и др.; 12 - шовные зоны и их номера: I - Голованевская, II - Ингулецко-Криворожская; 13 - массивы гранитоидов и их номера: III - Корсунь-Новомиргородский плутон, IV - Новоукраинский массив; 14 - номера зон разломов, в соответствии с [Gintov, Mychak, 2011]; 15 номера зон скалывания, по [Gintov, Mychak, 2011].

Fig. 10. Structural tectonophysical map of the Ingulsky megablock (from [Gintov, Mychak, 2011]).

1 - echelon and elementary shearing in fault zones formed: a - in the Neo-Arhean $\left(A R_{3}\right), \sigma$ - in the Neo-Arhean-Early Proterozoic $\left(A R_{3}-P_{1}-I\right)$, в - at the beginning of the Early Proterozoic $\left(\mathrm{PR}_{1}-\mathrm{I}\right), \Gamma-$ at the end of the Early Proterozoic $\left(\mathrm{PR}_{1}-\mathrm{II}\right)$, $\mathrm{A}-$ age not known; kinematic signs (blue during inception of the fault zones, yellow - during the main phase of activation); 2 - right-lateral shift; 3 - left-lateral shift; 4 - shear fault with normal component; 5 - shear fault with reverse component; 6 - dip direction; 7 - uplifted wing; 8 - subsided wing; 9 - spreading direction of the central part of the Ingulsky megablock; 10 - interregional zone of Kherson-Smolensk spreading; 11 - dykes of diabase, gabbro-diabase etc.; 12 suture zones and their numbers: I - Golovanevskaya, II - Inguletsko-Krivorozhskaya; 13 - granitoid massifs and their numbers: III - KorsunNovomirgorodsky pluton, IV - Novoukrainsky massif; 14 - numbers of fault zones according to [Gintov, Mychak, 2011]; 15 - numbers of shear zones according to [Gintov, Mychak, 2011]. 


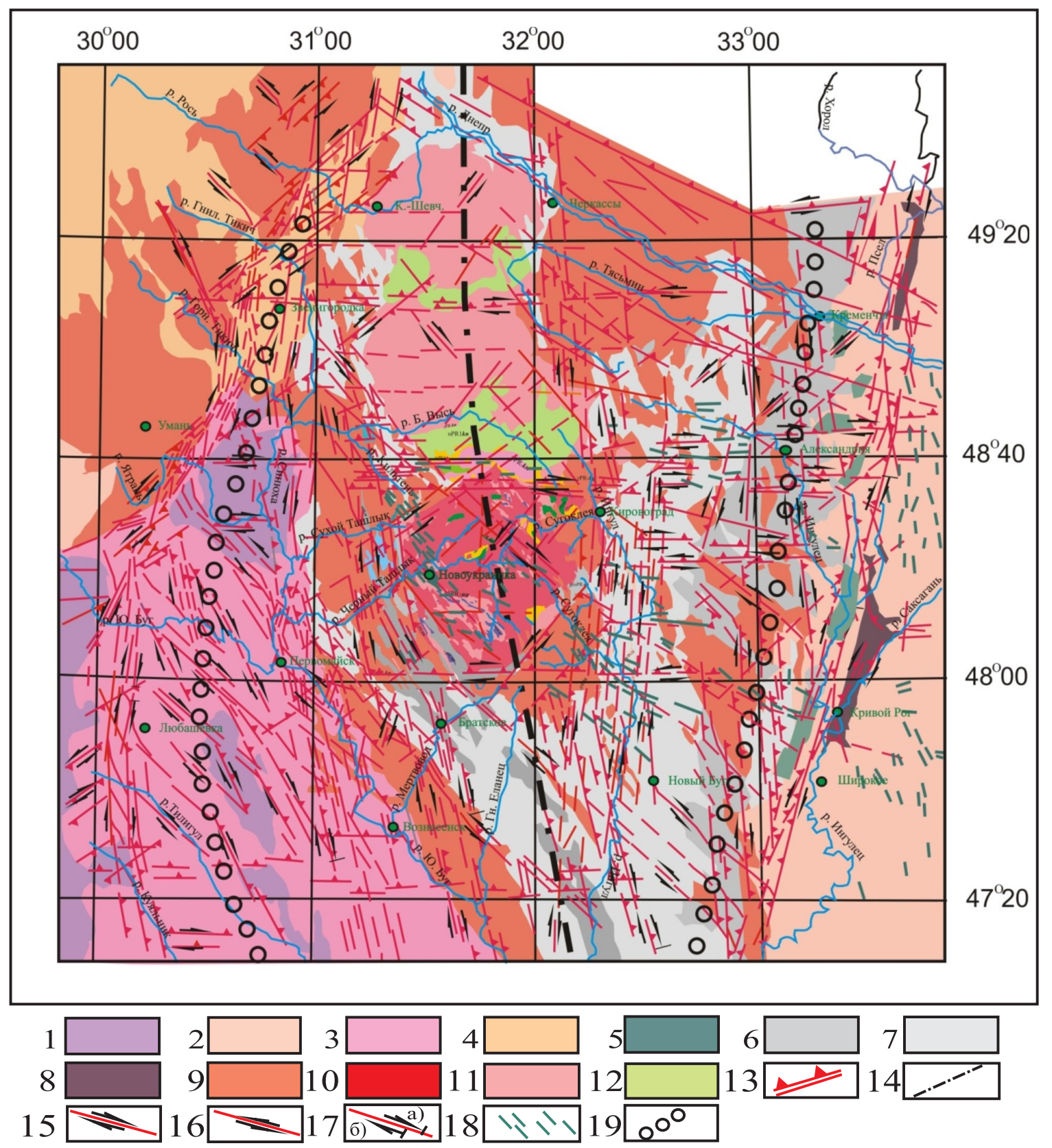

Рис. 11. Схема геологического строения Ингульского мегаблока (по [Gintov, Mychak, 2011]).

Серии и комплексы: 1 - днестровско-бугская, гайворонский $\left(\mathrm{AR}_{1}\right) ; 2$ - аульская, конкская, днепропетровский (AR $)_{1}$, ингулецкий, саксаганский, демуринский, токовский $\left(\mathrm{AR}_{2}\right) ; 3$ - бугская, капитановско-деренюхинский $\left(\mathrm{AR}_{3}\right)$, побужский $\left(\mathrm{PR}_{1}-\mathrm{I}\right) ; 4-$ росинско-тикичская $\left(\mathrm{AR}_{3}\right)$, звенигородский, гайсинский $\left(\mathrm{PR}_{1}-\mathrm{I}\right)$; ингуло-ингулецкая $\left(\mathrm{PR}_{1}-\mathrm{I}\right) ; 5$ - зеленореченская, артемовская, родионовская свиты; 6 - спасовская, каменно-костоватская свиты; 7 - рощаховская, чечелеевская свиты; 8 - криворожская (PR 1 -I); 9 - кировоградский, уманский, ставищанский $\left(\mathrm{PR}_{1}-\mathrm{I}\right) ; 10$ - новоукраинский $\left(\mathrm{PR}_{1}-\mathrm{I}\right) ;$ корсунь-новомиргородский $\left(\mathrm{PR}_{1}-\mathrm{II}\right) ; 11$ - рапакививидные граниты; 12 - габброанортозиты; 13 - эшелонированные сколы (сместители) зон разломов (берг-штрихи указывают направление падения); 14 - трансрегиональный тектонический шов Херсон - Смоленск; кинематические знаки для зон разломов: 15 - правый сдвиг, 16 - левый сдвиг, 17 сбросо-сдвиг (а), взбросо-сдвиг (б); 18 - дайки габбро-диабазов, лампрофиров и др.; 19 - осевые линии Голованевской (на западе) и Ингулецко-Криворожской (на востоке) шовных зон.

Fig. 11. Geological structure of the Ingulsky megablock (from [Gintov, Mychak, 2011]).

Series and complexes: 1 - Dnestrovsko-Bugskaya, Gaivoronsky $\left(\mathrm{AR}_{1}\right) ; 2$ - Aulskaya, Konkskaya, Dnepropetrovsky (AR $)_{1}$, Inguletsky, Saksagansky, Demurinsky, Tokovsky $\left(\mathrm{AR}_{2}\right) ; 3$ - Bugskaya, Kapitanovsko-Derenyukhinsky $\left(\mathrm{AR}_{3}\right)$, Pobuzhsky (PR $\left.-\mathrm{I}\right) ; 4$ - Rosinsko-Tikichskaya $\left(\mathrm{AR}_{3}\right)$, Zvenigorodsky, Gaisinsky ( $\left.\mathrm{PR}_{1}-\mathrm{I}\right)$; Ingulo-Inguletskaya $\left(\mathrm{PR}_{1}-\mathrm{I}\right) ; 5$ - Zelenorechenskaya, Artyomovskaya, Rodionovskaya suites; 6 Spasovskaya, Kamenno-Kostovatskaya suites; 7 - Roshchakhovskaya, Checheleevskaya suites; 8 - Krivorozhskaya ( PR $_{1}$-I); 9 - Kirovogradskaya, Umanskaya, Stavishchansky ( $\mathrm{PR}_{1}$-I); 10 - Novoukrainsky ( $\left.\mathrm{PR}_{1}-\mathrm{I}\right)$; Korsun-Novomirgorodsky ( $\mathrm{PR}_{1}$-II); 11 - rapakivi-like granites; 12 - gabbroanorthosite; 13 - echelon shear (fault planes) in fault zones (hatched lines show dip directions); 14 - Kherson-Smolensk transregional tectonic suture; kinematic signs for fault zones: 15 - right-lateral shift, 16 - left-lateral shift, 17 - shear fault with normal component (a), shear fault with normal component (б); 18 - dykes of gabbro-diabase, lamprophyre etc.; 19 - axial lines of Golovanevskaya (west) and Inguletsko-Krivorozhskaya (east) suture zones. 


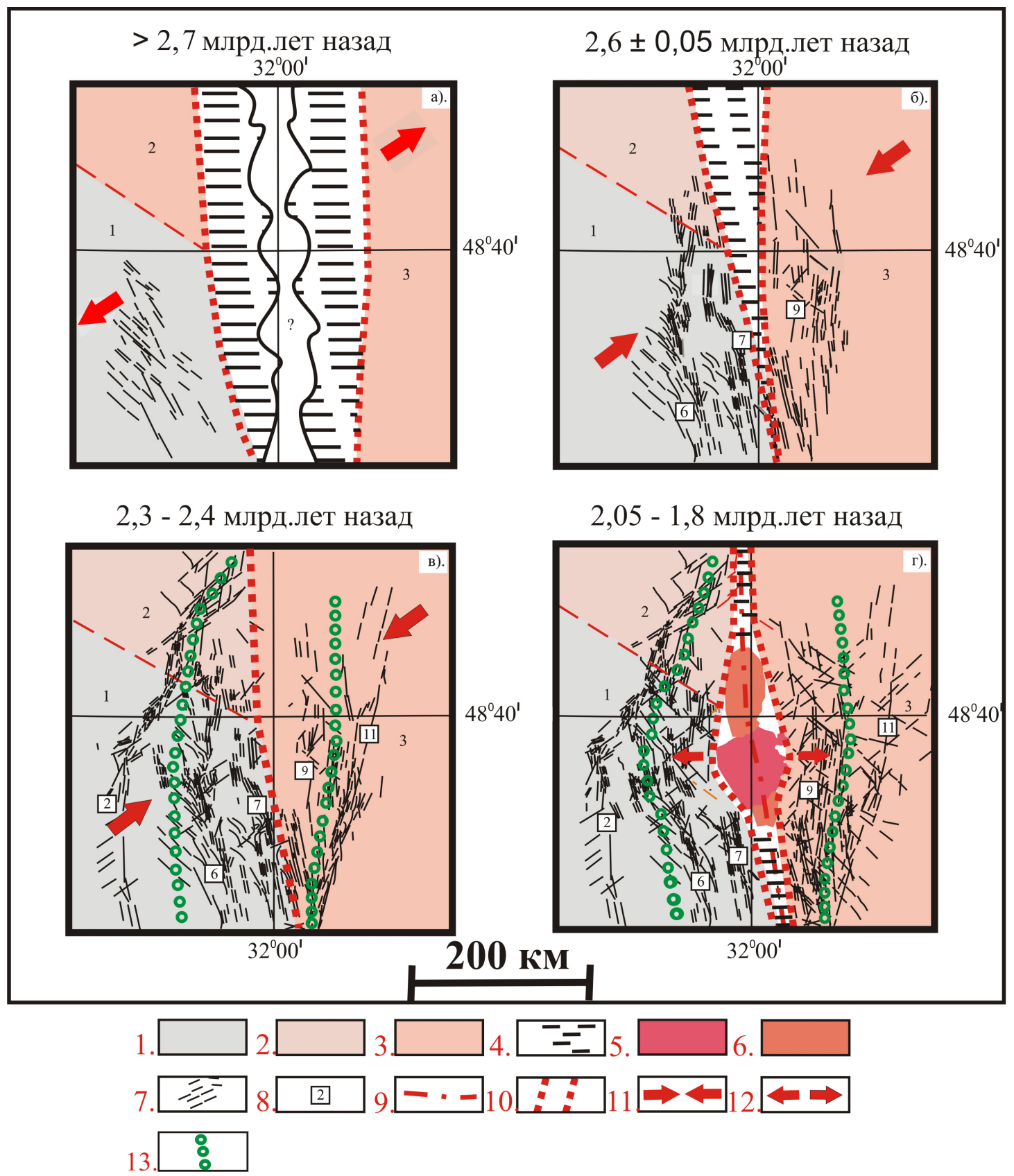

Рис. 12. Принципиальная схема перемещений Западной и Восточной микроплит УЩ в позднем архее - конце раннего протерозоя.

1-3 - усредненный состав земной коры микроплит (Западная: 1 - горные породы Днестровско-Бугского гранулитового пояса, 2 - росинско-тикичский амфиболит-гранитовый комплекс; Восточная: 3 - среднеприднепровский гранит-зеленокаменный комплекс); 4 - предполагаемая субокеаническая кора; 5 - гранитоиды новоукраинского комплекса; 6 - гранитоиды предполагаемого кировоградского комплекса; 7 - эшелонированный и элементарные сколы зон розломов; 8 - номера зон разломов, в соответствии с рис. 10; 9 - осевая линия трансрегиональной зоны раздвига Херсон - Смоленск; 10 - границы Западной и Восточной микроплит; 11 - направление сближения микроплит; 12 - направление раздвига микроплит; 13 - осевые линии шовных зон (на западе - Голованевской, на востоке - ИнгулецкоКриворожской). Зоны разломов: 2 - Тальновская, 6 - Первомайская, 7 - Звенигородско-Братская, 9 - Западно-Ингулецкая, 11 - Криворожско-Кременчугская.

Fig. 12. Schematic diagram showing movements of the Western and Eastern microplates of the Ukrainian Sheild in the Late Archean - end of Early Proterozoic.

1-3 - average composition of the crust in the microplates (Western: 1 - rocks of Dnestrovsko-Bugsky granulite belt, 2 - Rosinsko-Tikichsky amphibolite-granite complex: Eastern: 3 - Srednepridneprovsky granite-greenstone complex); 4 - supposed sub-oceanic crust; 5 - granitoids of Novoukrainsky complex; 6 - granitoids of supposed Kirovogradsky complex; 7 - echelone and elementary shears in faul zones; 8 - numbers of fault zones, as shown in Fig. 10; 9 - axial line of Kherson-Smolensk transregional spreading zone; 10 - borders of the Western and Eastern microplates; 11 - convergence direction of microplates; 12 - spreading direction of microplates; 13 - axial lines of suture zones (west - Golovanevskaya, east Inguletsko-Krivorozhskaya). Fault zones: 2 - Talnovsky, 6 - Pervomaisky, 7 - Zvenigorodsko-Bratsky, 9 - Zapadno-Inguletsky, 11 - Krivorozhsko-Kremenchugsky. 
O.B. Gintov et al.: Field tectonophysics in solutions of geodynamic evolution problems...

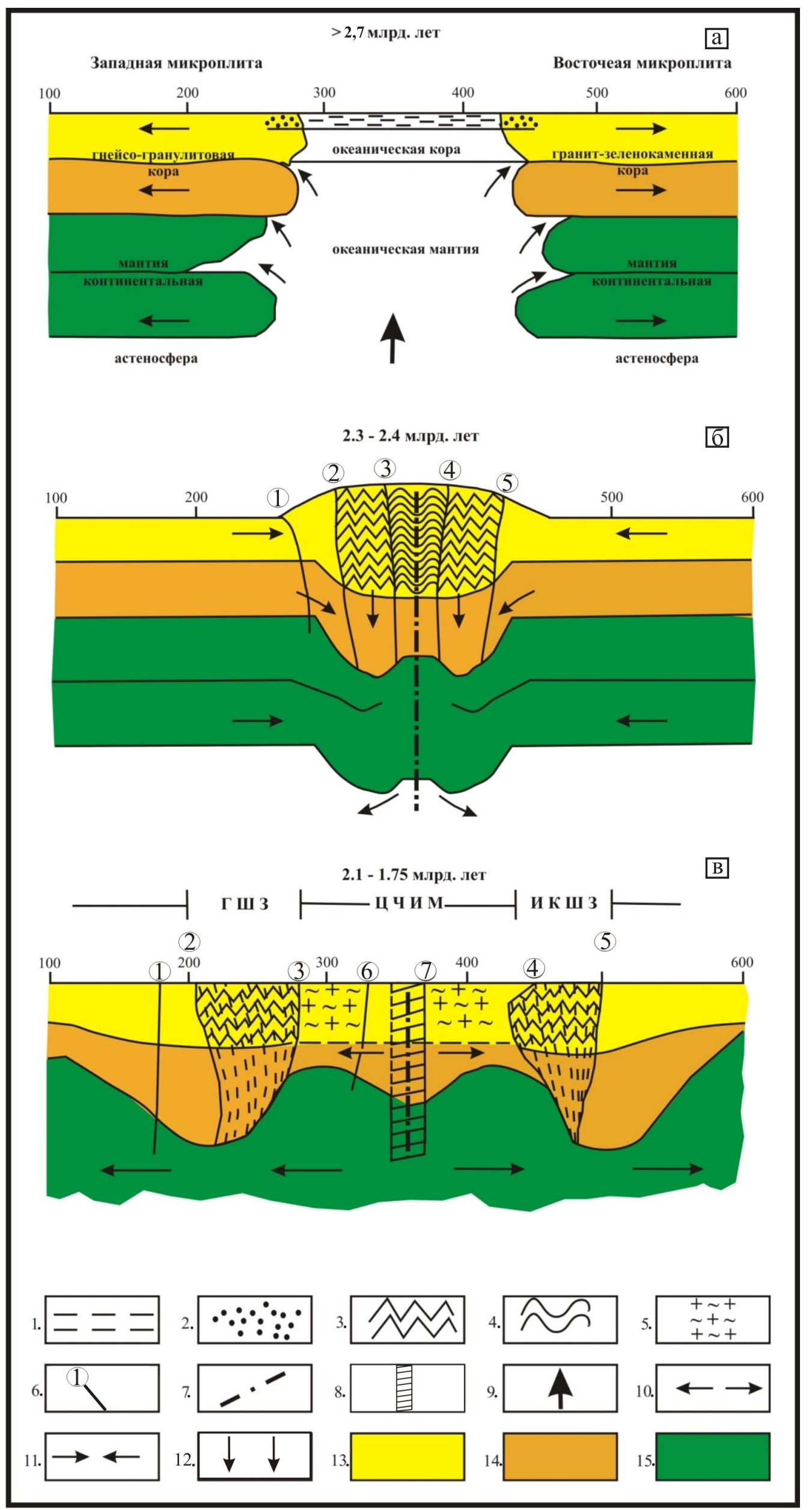


Рис. 13. Упрощенная схема геодинамического развития центральной части УЩ в неоархее - раннем протерозое (в разрезе).

1 - океанический бассейн; 2 - отложения бугской (на западе) и криворожской (на востоке) серий; 3 - складчатость в породах бугской и криворожской серий; 4 - складчатость в породах ингуло-ингулецкой серии; 5 - гранитизированные породы ингуло-ингулецкой серии, гранитоиды кировоградского, новоукраинского и корсунь-новомиргородского комплексов; 6 - осевые линии зон разломов (цифры в кружках): 1 - Одесской, 2 - Тальновской, 3 - Первомайской, 4 - Западноингулецкой, 5 - Криворожско-Кременчугской, 6 - Звенигородско-Братской, 7 - Кировоградской; 7 - осевая линия трансрегиональной зоны раздвига Херсон-Смоленск; 8 - минимальная ширина зоны; 9 - направление подъема неоархейского плюма; 10 - направление раздвига микроплит; 11 - направление сближения микроплит; 12 удлинение УГО по вертикали; 13 - верхняя кора; 14 - нижняя кора; 15 - мантия. Буквенные обозначения: ГШЗ - Голованевская шовная зона, ЦЧИМ - центральная часть Ингульского мегаблока, ИКШЗ - Ингулецко-Криворожская шовная зона.

Fig. 13. Simplified diagram showing geodynamic development of the central part of the Ukranian Shield in the Neo-Arhean - Early Proterozoic (profile).

1 - oceanic basin; 2 - deposits of Bugskaya (west) and Krivorozhskaya (east) series; 3 - folding in Bugskaya and Krivoy Rog series; 4 - folding in rocks of Ingulo-Inguletskaya series; 5 - granitized rocks of Ingulo-Inguletskaya series, granitoids of Kirovogradsky, Novoukrainsky and KorsunNovomirgorodsky complexes; 6 - axial lines of fault zones (numbers in circles): 1 - Odessky, 2 - Talnovsky, 3 - Pervomaysky, 4 - Zapadnoinguletsky, 5 - Krivorozhsko-Kremenchugsky, 6 - Zvenigorodsko-Bratsky, 7 - Kirovogradsky; 7 - axial line of Kherson-Smolensk transregional spreading zone; 8 - minimum width of the zone; 9 - uplift direction of the Neo-Archean plume; 10 - spreading direction of microplates; 11 - convergence direction of microplates; 12 - vertical elongation of УГО; 13 - upper crust; 14 - lower crust; 15 - mantle. Letters: ГШ3 Golovanevskaya suture zone; ЦЧИМ - central part of the Ingulsky megablock; ИКШЗ - Inguletsko-Krivorozhskaya suture zone.

физических вариантов - поддвиг верхних горизонтов субокеанической литосферы под корово-мантийные пластины по пологим поверхностям срыва, одной из которых является раздел Мохо. Другой вариант - обдукция субокеанической коры на континентальную кору Западной и Восточной микроплит (во время подъема щита этот аллохтон мог быть размыт).

На рубеже 2.05 - 2.10 млрд лет назад начался раздвиг Западной и Восточной микроплит УЩ (рис. 12, 2, 13, в), который устанавливается полевыми тектонофизическими данными по полям субширотного растяжения земной коры при формировании Новоукраинского массива трахитоидных гранитов и Корсунь-Новомиргородского плутона габбро-анортозитов и рапакиви. Раздвиг привел к разделению общей шовной зоны на две - Голованевскую и Ингулецко-Криворожскую и отодвиганию их друг от друга на 150-200 км. Во время раздвига 2.05-2.10 млрд лет назад расплавы, флюиды и гидротермы получили возможность подъема в верхнюю кору, стимулируя процессы палингенеза (новоукраинские и кировоградские граниты) и рудообразования (уран, золото, литий и др.), а при повторном раздвиге 1.75 млрд лет назад в верхнюю кору интрудировала магма основного и кислого состава (плутон габбро-анортозитов и рапакиви). Между двумя этапами раздвига тектонофизическими данными фиксируется этап сжатия земной коры, способствовавший задержке рудных растворов в ее верхних горизонтах (ниже уровня эрозии). Зона раздвига стала местом формирования межрегиональной транстенсионной шовной зоны Херсон - Смоленск, протягивающейся субмеридионально через всю Восточно-Европейскую платформу.

\section{4. ЗАКЛЮЧЕНИЕ}

Приведенные результаты тектонофизического изучения двух геологически разных районов территории Украины, завершающие этапы формирования которых отстоят друг от друга на 2 млрд лет, показывают, что анализ истории геологического развития регионов наиболее эффективен при использовании плитотектонического подхода. Исследование напряженно-деформированного состояния земной коры на всех этапах ее развития свидетельствует, во-первых, об исключительной роли в орогеническом процессе тангенциальных сил и, во-вторых, о широком развитии при этом крупных субгоризонтальных сдвигов литосферы. Такое сочетание тектонических сил и движений выводит на первый план процессы мантийной конвекции и плюмтектоники и ограничивает возможности применения пульсационной гипотезы, которая также исходит из признания важного значения тангенциальных сил. Установление реверсного характера движений и инверсионных напряжений не может быть использовано в пульсационной гипотезе, так как эти движения достаточно кратковременны и происходят в разных направлениях, в зависимости от ориентации разломов. Такие движения часто наблюдаются при землетрясениях (эффект упругой отдачи и др.).

Выполненные исследования указывают также на важное значение комплексирования СПМТ и КМТ, позволяющего прослеживать развитие тектонических процессов во времени, без чего геодинамические построения невозможны.

\section{5. ЛИТЕРАТУРА}

Bogdanova S.V., Pashkevich I.K., Gorbatschev R., Orlyuk M.I., 1996. Riphean rifting and major Palaeoproterozoic crustal boundaries in the basement of the East European Craton: geology and geophysics. Tectonophysics 268 (1-4), 1-21.

http://dx.doi.org/10.1016/S0040-1951(96)00232-6. 
Chardon D., Gapais D., Cagnard F., 2009. Flow of ultra-hot orogens: a view from the Precambrian, clues for the Phanerozoic. Tectonophysics 477 (3-4), 105-118. http://dx.doi.org/10.1016/j.tecto.2009.03.008.

Devlaux D., Sperner B., 2003. New aspects of tectonic stress inversion with reference to the TENSOR program. Geological Society, Special Publications 212, 75-100.

Dovbnich M.M., Demianets S.N., 2009. Stress fields of the tectonosphere due to violation of geoisostasy and geodynamics of the Crimean Black Sea region. Geofizicheskiy Zhurnal 31 (2), 107-116 (in Russian) [Довбнич М.М., Демьянец С.Н. Поля напряжений тектоносферы, обусловленные нарушением геоизостазии и геодинамика Крымско-Черноморского региона // Геофизический журнал. 2009. Т. 31. № 2. С. 107-116].

Geyko V.S., Tsvetkova T.A., Shumlyanska L.A., Bugaenko I.V., Zayets L.N., 2005. Regional 3-D P-velocity model of the mantle of Sarmatia (south-west of the East-European Platform). Geofizicheskiy Zhurnal 27 (6), 927-939 (in Russian) [Гейко В.С., Цветкова Т.А., Шумлянская Л.А., Бугаенко И.В., Заец Л.Н. Региональная 3-D Р-скоростная модель мантии Сарматии (юго-запад Восточно-Европейской платформы) // Геофизический журнал. 2005. Т. 27. № 6. C. 927-939].

Gintov O.B., 2005. Field Tectonophysics and Its Application in Studies of Crustal Deformation in Ukraine. Phoenix, Kiev, 572 p. (in Russian) [Гинтов О.Б. Полевая тектонофизика и ее применение при изучении деформаций земной коры Украины. Киев: Феникс, 2005. 572 с.].

Gintov O.B., Isai V.M., 1988. Tectonophysical Studies of Faults in the Consolidated Crust. Naukova Dumka, Kiev, 228 p. (in Russian) [Гинтов О.Б., Исай В.М. Тектонофизические исследования разломов консолидированной коры. Киев: Наукова думка, 1988. 228 с.].

Gintov O.B., Murovskaya A.V., Mychak S.V., 2008. Integration of structural, paragenetical and kinematical methods as a prerequisite for progress in field tectonophysics. In: Tectonophysics and Current Problems of Earth Sciences. Proceedings of the All-Russia Conference. Institute of Physics of the Earth, RAS, Moscow, Vol. 1, p. 22-28 (in Russian) [Гинтов O.Б., Муровская А.В., Мычак С.В. Комплексирование структурно-парагенетического и кинематического методов - условие дальнейшего прогресса в полевой тектонофизике // Тектонофизика и актуальные вопросы наук о Земле: Материалы докладов Всероссийской конференции. М.: Институт физики Земли РАН, 2008. Т. 1. С. 22-28].

Gintov O.B., Mychak S.V., 2011. Geodynamic evolution of Ingulsky megablock of the Ukrainian shield according to geological, geophysical and tectonophysical data. 2. Geofizicheskiy Zhurnal 33 (4), 89-99 (in Russian) [Гинтов О.Б., Мычак C.B. Геодинамическое розвитие Ингульского мегаблока Украинского щита по геолого-геофизическим и тектонофизическим данным. 2 // Геофизический журнал. 2011. Т. 33. № 4. С. 89-99].

Gintov O.B., Pashkevich I.K., 2010. Tectonophysical analysis and geodynamical interpretation of three-dimensional geophysical model of the Ukrainian shield. Geofizicheskiy Zhurnal 32 (2), 3-27 (in Russian) [Гинтов О.Б., Пашкевич И.К. Тектонофизический анализ и геодинамическая интерпретация трехмерной геофизической модели Украинского щита // Геофизический журнал. 2010. Т. 32. № 2. С. 3-27].

Gushchenko O.I., 1979. Method of kinematic analysis of destruction structures at the reconstruction of fields of tectonic stressesю In: Fields of stresses and deformations in the lithosphere. Nauka, Moscow, p. 7-25 (in Russian) [Гущенко О.И. Метод кинематическеого анализа структур разрушения при реконструкции полей тектонических напряжений // Поля напряжений и деформаций в литосфере. М.: Наука, 1979. С. 7-25].

Murovskaya A.V., 2012. The stress-strained state of the Western Mountainous Crimea in the Oligocene-Quaternary according to tectonophysical data. Geofizicheskiy Zhurnal 34, (2), 109-119 (in Russian) [Муровская А.В. Напряженно-деформированное состояние Западного Горного Крыма в олигоцен-четвертичное время по тектонофизическим данным // Геофизический журнал. 2012. Т. 34. № 2. С. 109-119].

Patalaha E.I., Gonchar V.V., Senchenkov I.K., Chervinko O.P., 2003. The Indentor Mechanism in Geodynamics of the Crimean Black Sea region. Emko, Kiev, 226 p. (in Russian) [Паталаха Е.И., Гончар В.В., Сенченков И.К., Червинко О.П. Инденторный механизм в геодинамике Крымско-Черноморского региона. Киев: Эмко, 2003.226 с.].

Pustovitenko B.G., 2002. Focal mechanisms of perceptible earthquakes of the Crimean Black Sea region during the last 20 years. In: Seismological Bulletin of Ukraine, 2000. Publishing House of IG NASU, KES, Kiev, p. 59-64 (in Russian) [Пустовитенко Б.Г. Механизмы очагов ощутимых землетрясений Крымско-Черноморского региона последних 20 лет. Сейсмологический бюллетень Украины за 2000 год. Киев: Изд-во ИГ НАНУ, КЭС, 2002. С. 59-64].

Rebetsky Yu.L., 2002. The review of methods of reconstruction of tectonic stresses and seismotectonic deformations. In: Tectonophysics today. JIPE RAS, Moscow, p. 227-243 (in Russian) [Ребецкий Ю.Л. Обзор методов реконструкции тектонических напряжений и сейсмотектонических деформаций // Тектонофизика сегодня. М.: ОИФЗ РАН, 2002. C. 227-243].

Shcherbak N.P., 2005. Geochronology of the Early Precambrian Ukrainian Shield. The Archean. Naukova Dumka, Kiev, 244 p. (in Russian) [Щербак Н.П. Геохронология раннего докембрия Украинского щита. Архей. Киев: Наукова думка, 2005. 244 c.].

Shcherbak N.P., 2008. Geochronology of the Early Precambrian of the Ukrainian Shield. The Proterozoic. Naukova Dumka, Kiev, 240 p. (in Russian) [Щербак Н.П. Геохронология раннего докембрия Украинского щита. Протерозой. Киев: Наукова думка, 2008. 240 с.].

Sizova E., Gerya T., Brown M., Perchuk L., 2010. Subduction styles in the Precambrian: Insight from numerical experiments. Lithos 116 (3-4), 209-229. http://dx.doi.org/10.1016/j.lithos.2009.05.028. 
Volfman Yu.M., 2008. The effect of kinematic environments on the cyclical geological processes within the Crimea and the Northern Black Sea region during the Alpine stage. Geofizicheskiy Zhurnal 30 (5), 101-114 (in Russian) [Вольфман Ю.М. О влиянии кинематических обстановок на цикличность геологических процессов в пределах Крыма и Северного Причерноморья в течение альпийского этапа // Геофизический журнал. 2008. Т. 30. № 5. С. 101-114].
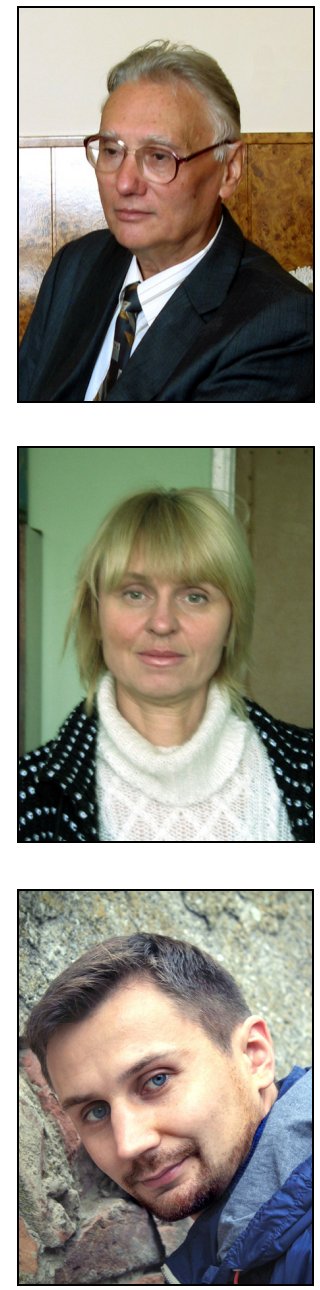

Гинтов Олег Борисович, член-корреспондент НАН Украины, докт. геол.-мин. наук, профессор, г.н.с. отдела тектонофизики

Институт геофизики им. С.И. Субботина НАН Украины

03680, Киев, пр. Палладина, 32, Украина

Тел.: +38(044)4240300; моб. +38(097)1720971; \ e-mail: oleg.gintov@gmail.com

Gintov, Oleg B., Corresponding Member of NAS of Ukraine, Doctor of Geology and Mineralogy, professor, Chief Researcher of Department of Tectonophysics

S.I. Subbotin Institute of Geophysics, NAS of Ukraine

32 Palladin prospect, Kiev 03680, Ukraine

Tel.: +38(044)4240300; mobile +38(097)1720971; $\bowtie$ e-mail: oleg.gintov@gmail.com

Муровская Анна Валериевна, канд. геол. наук, м.н.с. отдела тектонофизики

Институт геофизики им. С.И. Субботина НАН Украины

03680, Киев, пр. Палладина, 32, Украина

Тел.: +38(044)4240300, моб. +38(098)5238820; e-mail: murovskaya@gmail.com

Murovskaya, Anna V., Candidate of Geology, Junior Researcher of Department of Tectonophysics S.I. Subbotin Institute of Geophysics, NAS of Ukraine

32 Palladin prospect, Kiev 03680, Ukraine

Tel.: +38(044)4240300, mobile +38(098)5238820; e-mail: murovskaya@gmail.com

Мычак Сергей Владимирович, канд. геол. наук, м.н.с. отдела тектонофизики

Институт геофизики им. С.И. Субботина НАН Украины

03680, Киев, пр. Палладина, 32, Украина

Тел.: +38(044)4246156, моб. +38(097)6884656; e-mail: Mychak_S@ukr.net

Mychak, Sergei V. Candidate of Geology, Junior Researcher of Department of Tectonophysics

S.I. Subbotin Institute of Geophysics, NAS of Ukraine

32 Palladin prospect, Kiev 03680, Ukraine

Tel.: +38(044)4246156, mobile +38(097)6884656; e-mail: Mychak_S@ukr.net 